


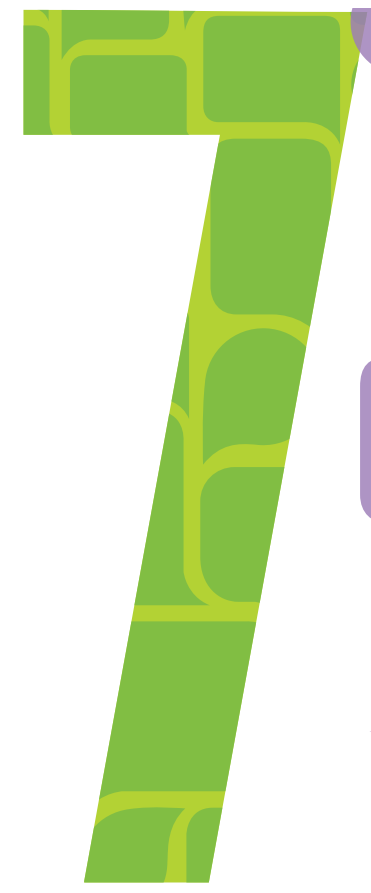




\section{Dossiê curatorial}

Após toda a pesquisa realizada, iniciamos a elaboração do dossiê curatorial, no qual será inserido os conceitos do projeto expográfico proposto, bem como toda a elaboração da linguagem visual. Os elementos gráficos que irão compor os materiais desse projeto expográfico foram pensados à partir de nossos estudos realizados ao longo dessa pesquisa teórica. Com o intuito de aplicar os conceitos de memória individual e coletiva nos materiais gráficos e nas instalações.

\subsection{Conceito}

Com base nas pesquisas realizadas, foi possível observar que o projeto Morro da Macumba, assim como o bairro Parque Residencial Cocaia são formados pelas memórias individuais dos moradores que, por meio dos depoimentos, transformaram-se em histórias que compõem a memória coletiva.

Maurice Halbwachs ${ }^{31}$ (1990, p. 23) ressalta que a memória individual existe porque o indivíduo está em uma constante busca de identidade e as memórias coletivas são fundamentais para isso. HALBWACHS complementa:

O indivíduo carrega em si a lembrança, mas está sempre interagindo com a sociedade, seus grupos e instituições. $E$ no contexto destas relações que construímos as nossas lembranças. A rememoração individual se faz na tessitura das memórias dos diferentes grupos com que nos relacionamos.

Partindo deste contexto da memória, observamos também que ela se transforma em algo concreto quando os indivíduos comunicam essas lembranças e essa ocorre principalmente na forma oral. Assim, o projeto Morro da Macumba é uma narrativa gráfica da história do bairro, que foi composta pelos depoimentos relatados pelos moradores na forma oral, que foram transcritos e aplicados com a arte na fachada das casas.

Após nossa pesquisa, decidimos pelo nome da exposição como Memórias do Morro, onde apresentamos as diferentes memórias presentes no projeto Morro da Macumba como peças-chaves na formação do espaço do bairro.
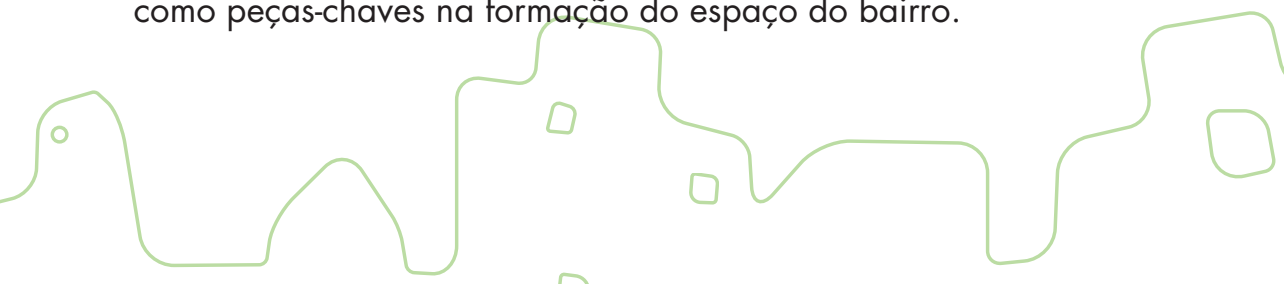

31 Geraldo Ivan de Souza, pernambucano, mora no bairro há 20 anos. 


\subsection{Linguagem Visual}

Todos os itens relacionados anteriormente devem buscar essa premissa, explorando tanto graficamente quanto em forma de popup, os elementos que podem ser encontrados no projeto original Morro da Macumba e que será o diferencial desse novo projeto.

Os elementos gráficos que serviram de apoio para a construção da linguagem visual estão divididos à seguir.

\subsubsection{Paleta cromática}

O conjunto de cores que formam a linguagem visual do projeto está diretamente ligada ao projeto original. O projeto Morro da Macumba utiliza uma vasta gama de cores, que o torna atrativo e impactante. As cores selecionadas são:
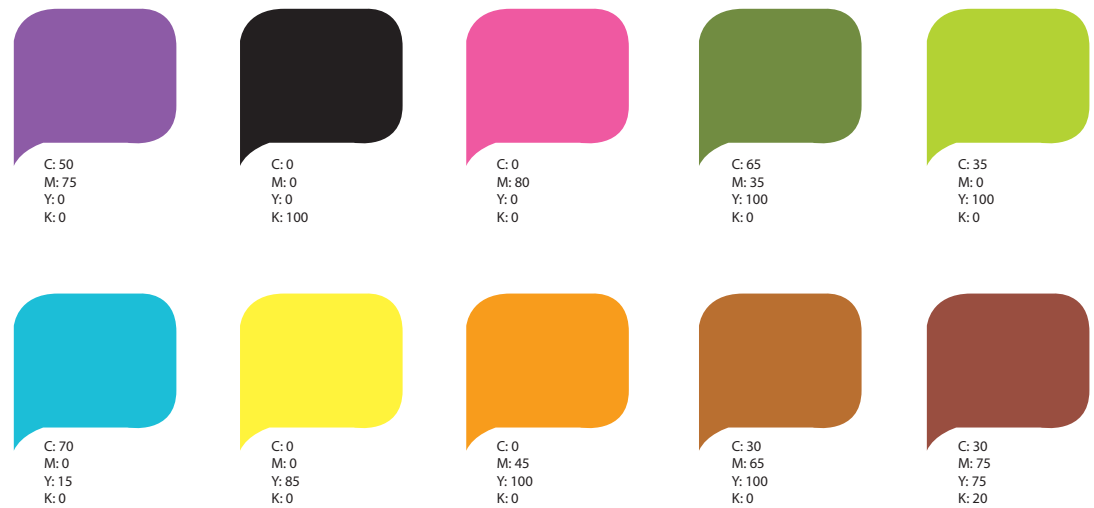

\subsubsection{Tipografia}

Utilizamos duas famílias tipográficas: uma para logotipo e outra para os textos dos materiais impressos e da cenografia das instalações. A tipografia que usamos para a composição do logotipo possui algumas características:

\section{Sem serifa}

A família tipográfica principal (que será utilizada para a confecção do logotipo da exposição e toda a parte tipográfica dos títulos dos materiais gráficos, desde o catálogo até os materiais de divulgação) deverá ser sem serifa, pois nossa linguagem visual se baseia em 3 eixos centrais: memórias (depoimentos), histórias em quadrinhos e grafitti. Os dois últimos eixos ( $\mathrm{HQ}$ e grafitti) possuem linguagem características: o $\mathrm{HQ}$ por fazer o uso de fontes sem serifas nos textos e o grafitti pelo uso de letras mais estilizadas (arredondadas) e que, portanto, servirão de base para a criação da linguagem visual. 


\section{Alusão ao HQ}

Como afirmado anteriormente, a busca de elementos que remetam ao universo dos quadrinhos poderão ser utilizados como elementos visuais para a confecção da linguagem. A tipografia por sua vez terá papel fundamental, sendo ela simplificada, de boa legibilidade e que remonte a elementos de $\mathrm{HQ}$.

Dentro dessas definições escolhemos a seguinte tipografia:

Armor Piercing

\section{ARCDEFCUIJKLTROPQRSTUVUXUZ}

\section{0, . : ? / []()}

Para as massas de texto escolhemos a família Futura, por ser uma fonte de alta legibilidade, além de ser utilizada como fonte de leitura em muitas exposições:

\section{Futura Md BT}

ABCDEFGHIJKLMNOPQRSTUVWXYZ

abcdefghijkImnopqrsturwxyz

$1234567890,$. : ^ () [] ? /

ABCDEFGHIJKLMNOPQRSTUVWXYZ

abcdefghijklmnopqrsturwxyz

$1234567890,$. : ^ () []? /

AB CDEFGHIJKLMNOPQRSTUVWXYZ

abcdefghijkImnopqrstuvwxyz

$1234567890, \ldots$ : () [] ? /

ABCDEFGHIJKLMNOPQRSTUVWXYZ

abcdefghijklmnopqrstuvwxyz

$1234567890, \ldots$ : () [] ? /

\subsubsection{Elemento gráfico}

O elemento gráfico que compõe a linguagem visual é o balão de fala de histórias em quadrinhos. Fazendo alusão aos $\mathrm{HQ}_{\mathrm{s}}$, os balões também simbolizam os depoimentos, as falas. Sua aplicação em diferentes formatos simbolizam os diferentes depoimentos dos moradores do Morro, que em conjunto formam as memórias individuais e coletiva. 

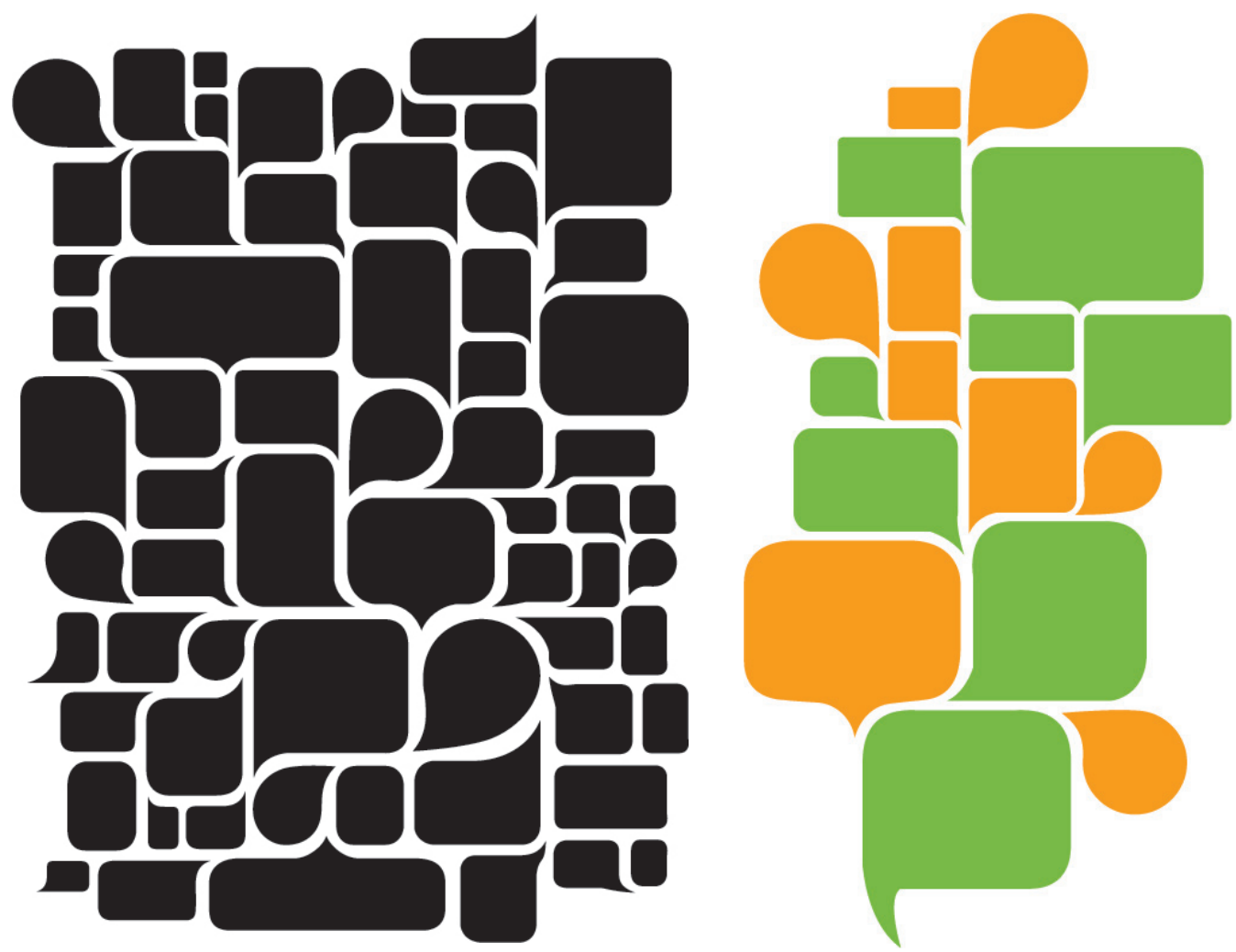

As aplicações dos balões em diferentes tamanhos e formatos formam uma malha que foi trabalhada em conjunto com a paleta de cores definidas para o projeto. Essa malha trabalhará com a dualidade onde o fundo terá uma cor mais forte e os balões com uma cor mais clara, porém menos chamativa para não tornar a peça carregada e cansativa. Com isso, criamos uma textura de balões, que aparentam "tijolos", pois refletem que esse projeto foi construído a partir das memórias.

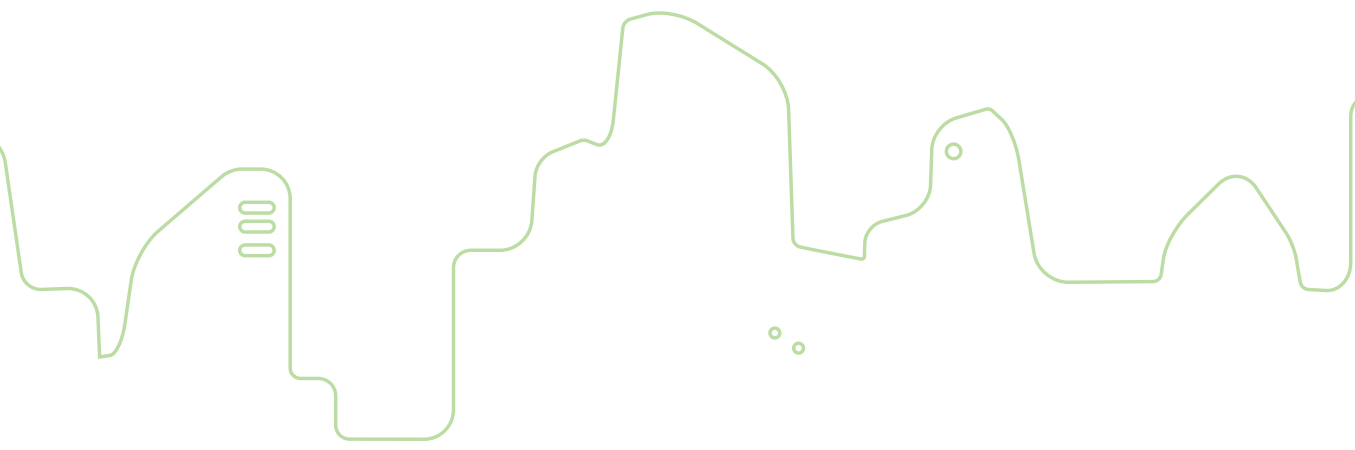




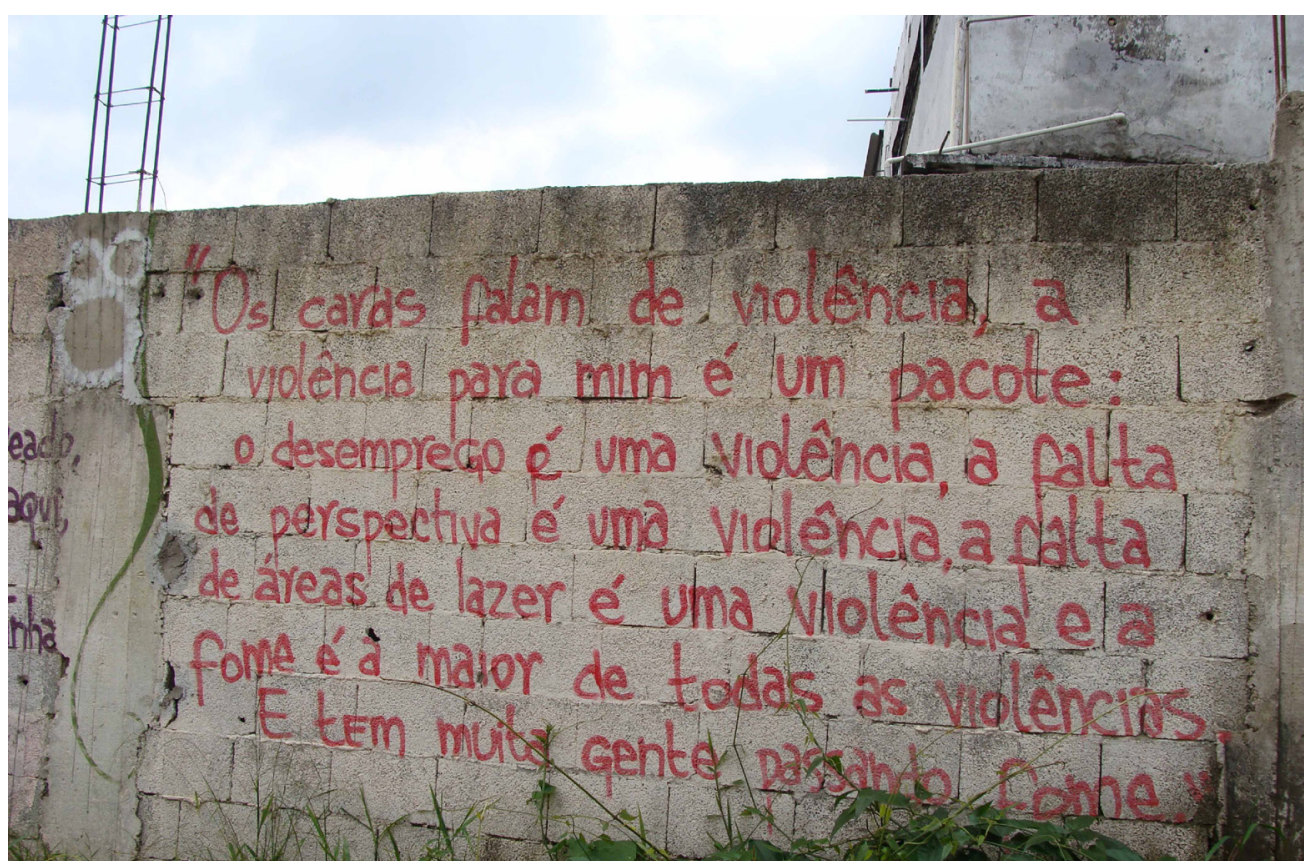

A ideia dos balões foi utilizada também na criação do logotipo da exposição. Este é formado por quatro balões de diferentes formatos e tamanhos, com a distribuição do nome da exposição.

Outro elemento gráfico de impacto que também é aplicado no conjunto da linguagem visual foi elaborado pensando na própria construção da exposição. A parte externa é montada formando duas letras " $M$ ", letras iniciais do nome do projeto, e que 
funcionam como as portas de entrada e saída da exposição. O elemento gráfico possui um forte impacto se utilizado como popup nos materiais gráficos e essa possibilidade de aplicação diferenciada desse símbolo contribui para o interesse do publico em ver a exposição. Suas formas simples possibilitam também que ele possa formar um padrão gráfico, tal qual a aplicação dos balões.

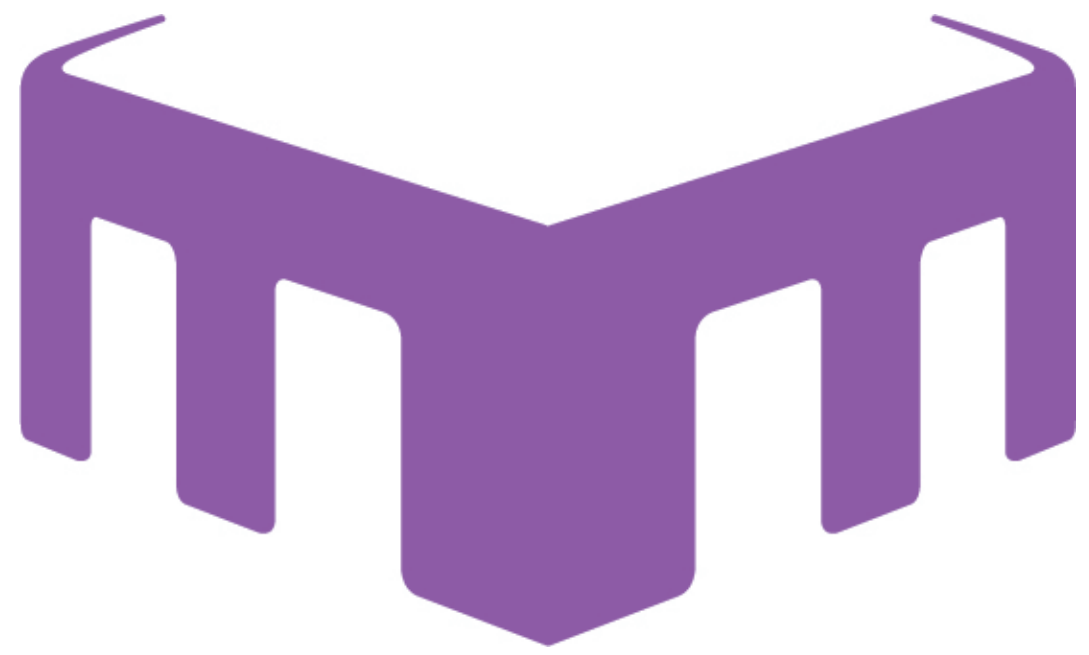

Para representar a irregularidade das casas do Morro da Macumba, foi criado um elemento gráfico de uma linha de casas irregulares, que foi aplicado nos materiais impressos como uma maneira de representar que as memórias sairam do Morro.

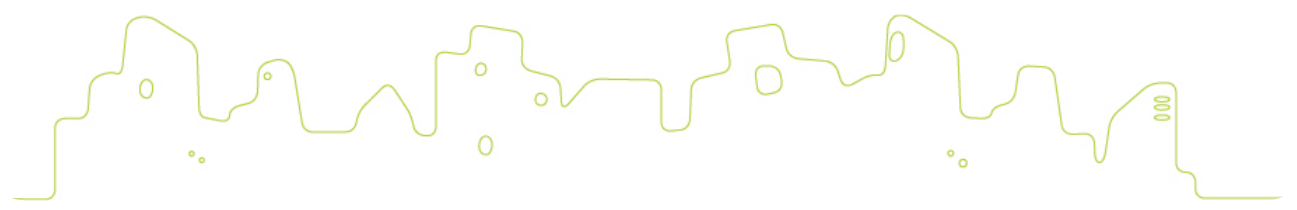

\subsection{Plano de comunicação}

A comunicação, como observado ao longo da pesquisa é um diferencial para a exposição. Pensando nisso, elaboramos um planejamento que visa a divulgação antes, durante e após a exposição e dos materiais que precisaremos entregar ao final do projeto:

\section{Elaboração}

- Elaborar planejamento de divulgação

- Elaborar inauguração
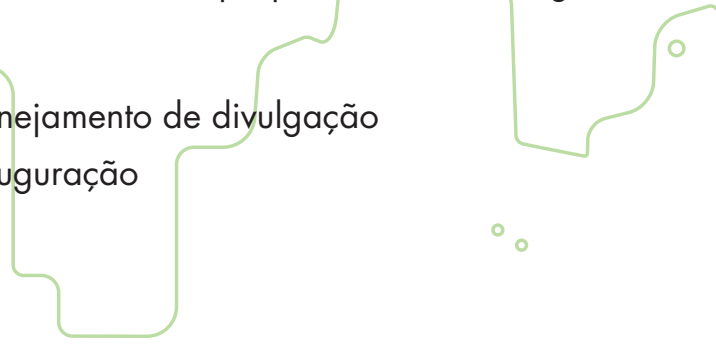
- Elaborar planejamento do Fórum de discussão - pauta, convidados, agenda, E-MKT, PDF com todas as informações.

- Apresentação

- Relatório de qualidade da exposição

- Material de apresentação do projeto todo ("portfólio") - finalizar

- Fotos da exposição

\section{Divulgação}

- Nas principais mídias do metrô

- Em escolas, bibliotecas, espaços de exposição

- Colagem de lambes pelos muros da cidade

- Releses em cadernos de arte, cultura e entretenimento de jornais como Destak e Metro

\section{Entrega}

- Relatórios para patrocinadores e apoiadores.

- Inauguração

- Apresentação (banca)

- Todo material do trabalho (banca)

\section{Inscrição}

- Inscrição do projeto em atividades artístico-sociais (enviar o "portfólio" da exposição).

\section{Relatórios pós exposição}

- Verificar se todo o plano de comunicação foi bem feito e se cumpriu com os objetivos

- Atendimento de prazos de montagem

- Frequência de público

- Avaliação de compreensão dos objetivos propostos aos visitantes

- Relacionar quantidade de material para cada patrocinador de acordo com as respectivas cotas

- Dossie de imagens contendo fotos do processo de confecção, do período de realização da exposição e de desmontagem

- Com esse planejamento de comunicação, foram elaborados materiais que serão utilizados para a divulgação da exposição: 


\subsubsection{Cartazes}

Os cartazes são mídias comuns para divulgação de exposições. Pensando em uma maneira de criar um diferencial para os cartazes, elaboramos três tipos:

Principal - contém o logo da exposição e as principais informações da exposição, bem como os patrocinadores.

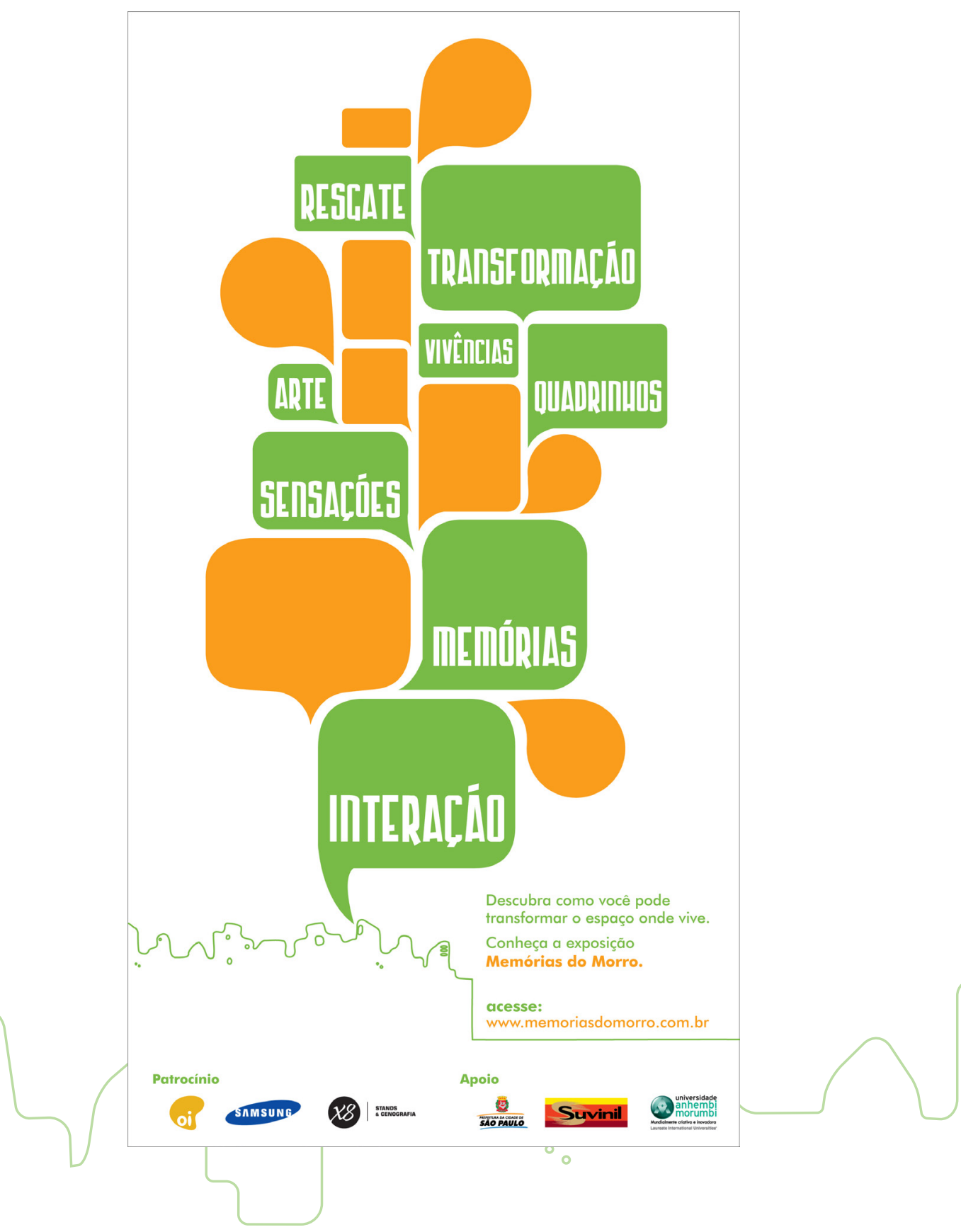


Virais - cartazes para despertar curiosidade; em cada um desses, escolhemos uma palavra que represente o projeto, aplicado com uma frase, além das informações principais da exposição e os patrocinadores. Esses cartazes poderão ser utilizados como lambe-lambes nos muros da cidade, como uma forma de divulgação.
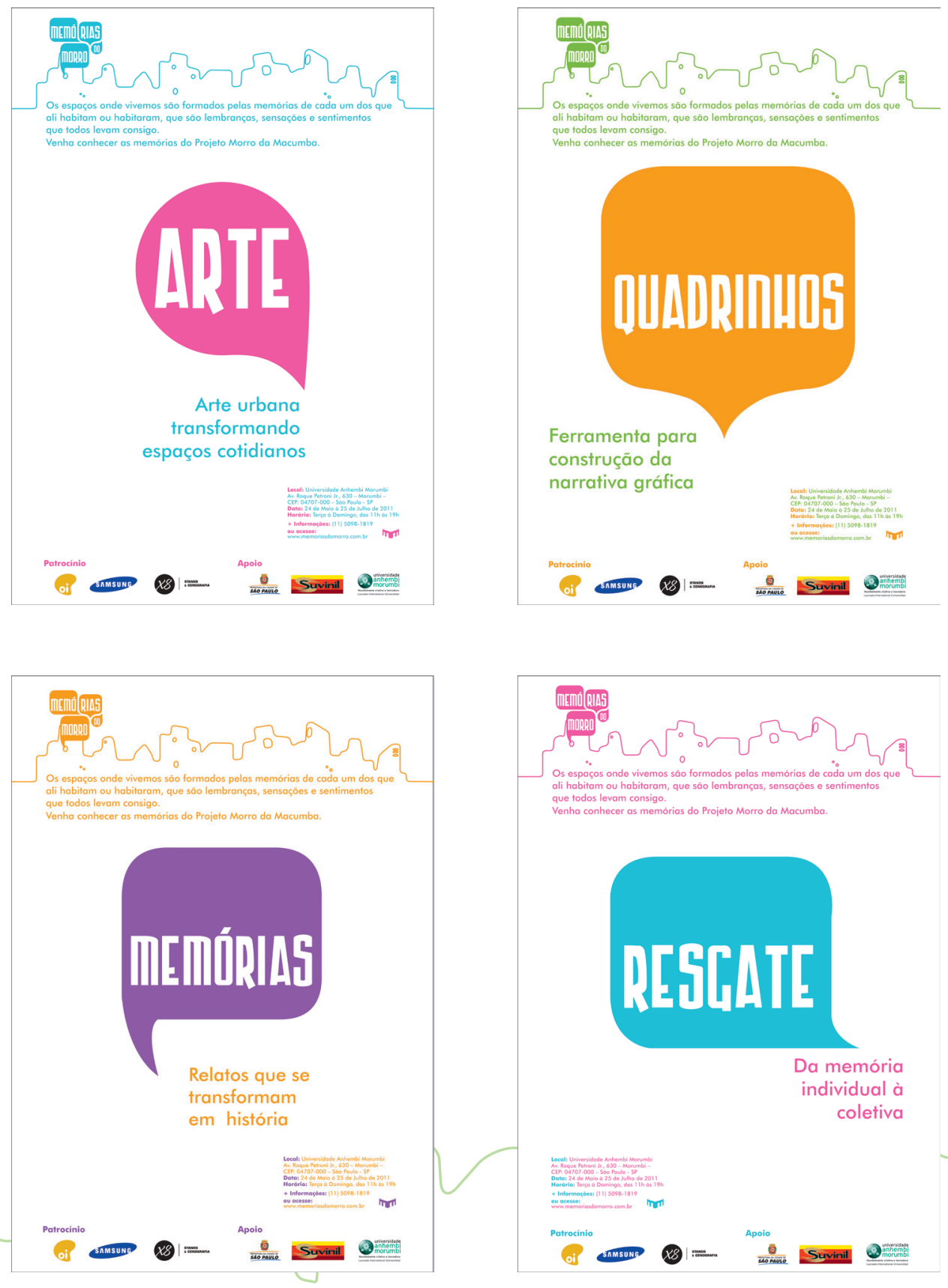
Ambos os cartazes aqui mencionados foram confeccionados em formato A2 (para mídias do metrô) e A3 (para universidades, instituições de ensino, bibliotecas e espaços culturais).

Horizontal do metrô - Esse cartaz foi elaborado para ser aplicado nas mídias superiores dos trens do metrô. Com formato de $1,12 \mathrm{~m} \times 0,30 \mathrm{~m}$, ele contém as informações principais da exposição, patrocinadores e uma tirinha com as imagens do projeto Morro da Macumba.

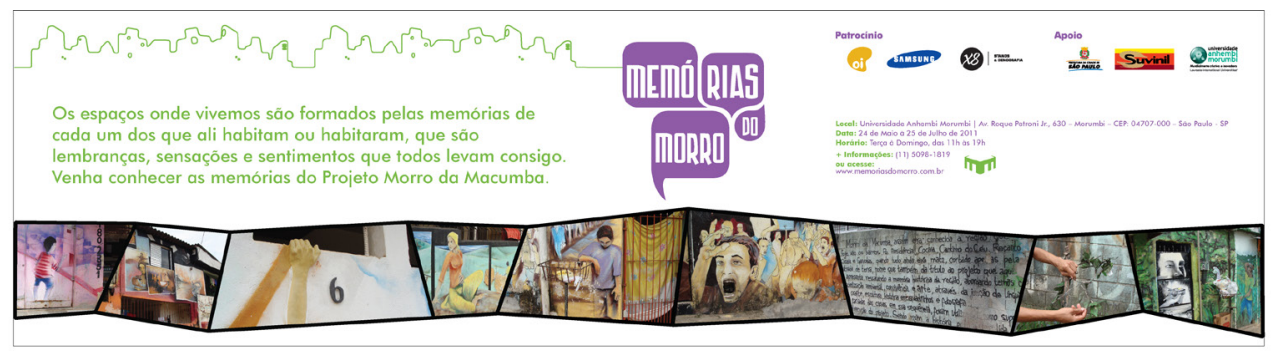

\subsubsection{Banner}

O banner de divulgação para ser colocado na Estação Sé de Metrô, por ter uma grande dimensão e por ter muitas pessoas que o visualizam. Ele é composto pela linha que representa as casas irregulares do Morro da Macumba. Acima, encontram-se os balões de memórias que passam a sensação de estarem saindo do Morro. Nesses balões, colocamos as palavras que norteiam o trabalho, além das informações principais da exposição e o endereço do hotsite, instigando as pessoas a entrerem neste espaço da web para conhecer e saber um pouco mais sobre a exposição. 


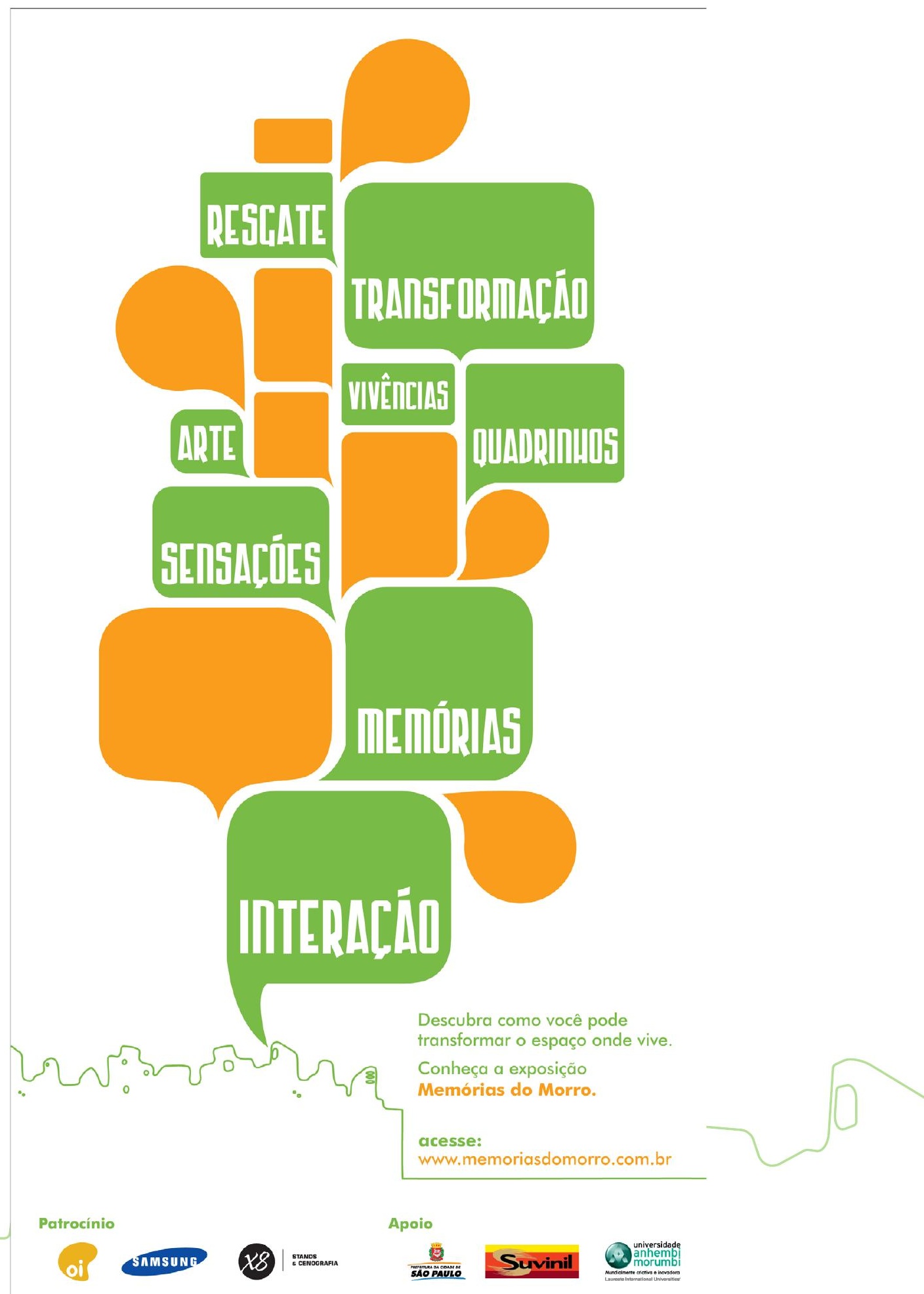




\subsubsection{Folder}

Buscando trabalhar com a interação nos materiais gráficos, elaboramos um envelope que remete a ideia de um envelope de carta, com as medidas $18 \times 13 \mathrm{~cm}$, para representar algo para ser guardado.
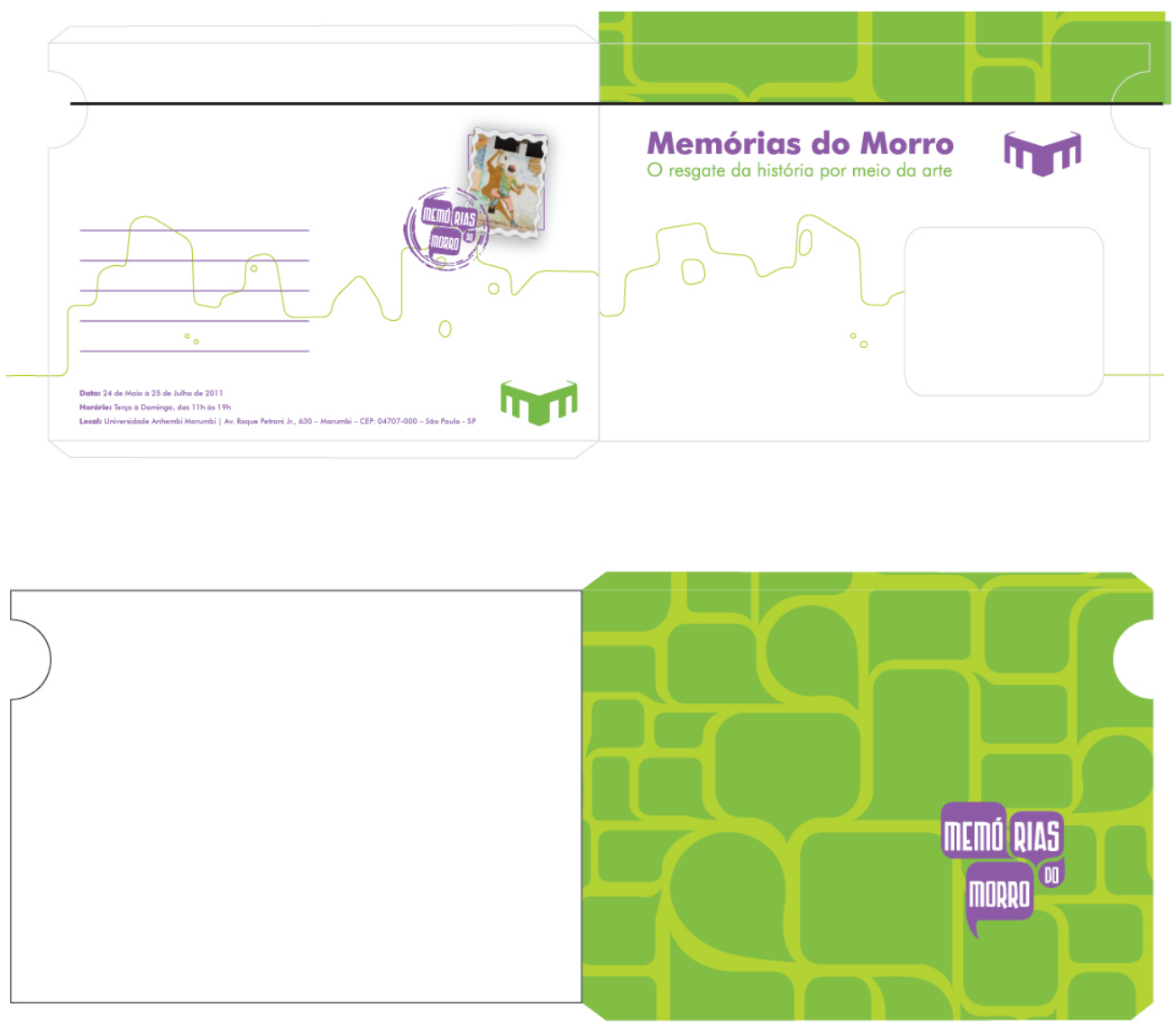

Dentro desse envelope, encontra-se o folder, em formato sanfonado, com as medidas de 18×30,5 (aberto). Nesse folder estão as principais informações sobre o que é o projeto. No verso, encontra-se a planta da exposição para que as pessoas possam guardar e levar no dia da visita e identificarem as áreas no qual estão visitando, além das informações de local, datas e horários e os patrocinadores. Esse material será utilizado na comunicação em polos culturais: museus, pinacotecas, instituições que apóiam eventos culturais.
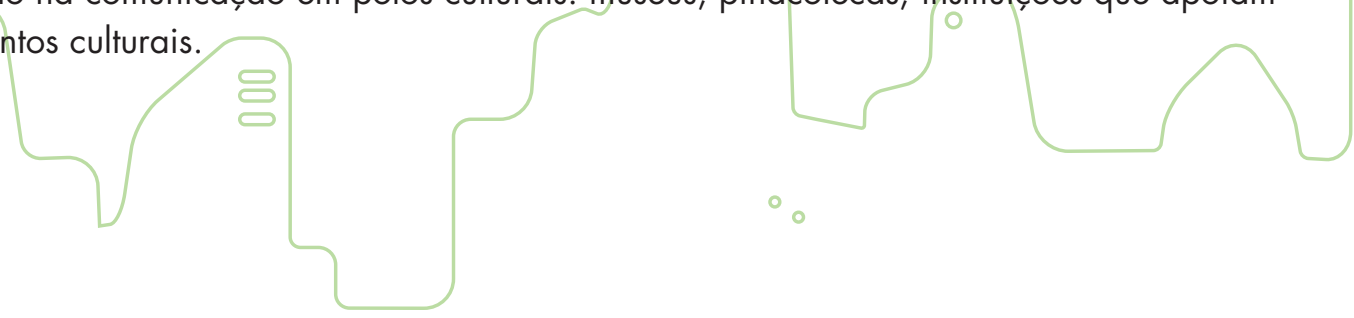

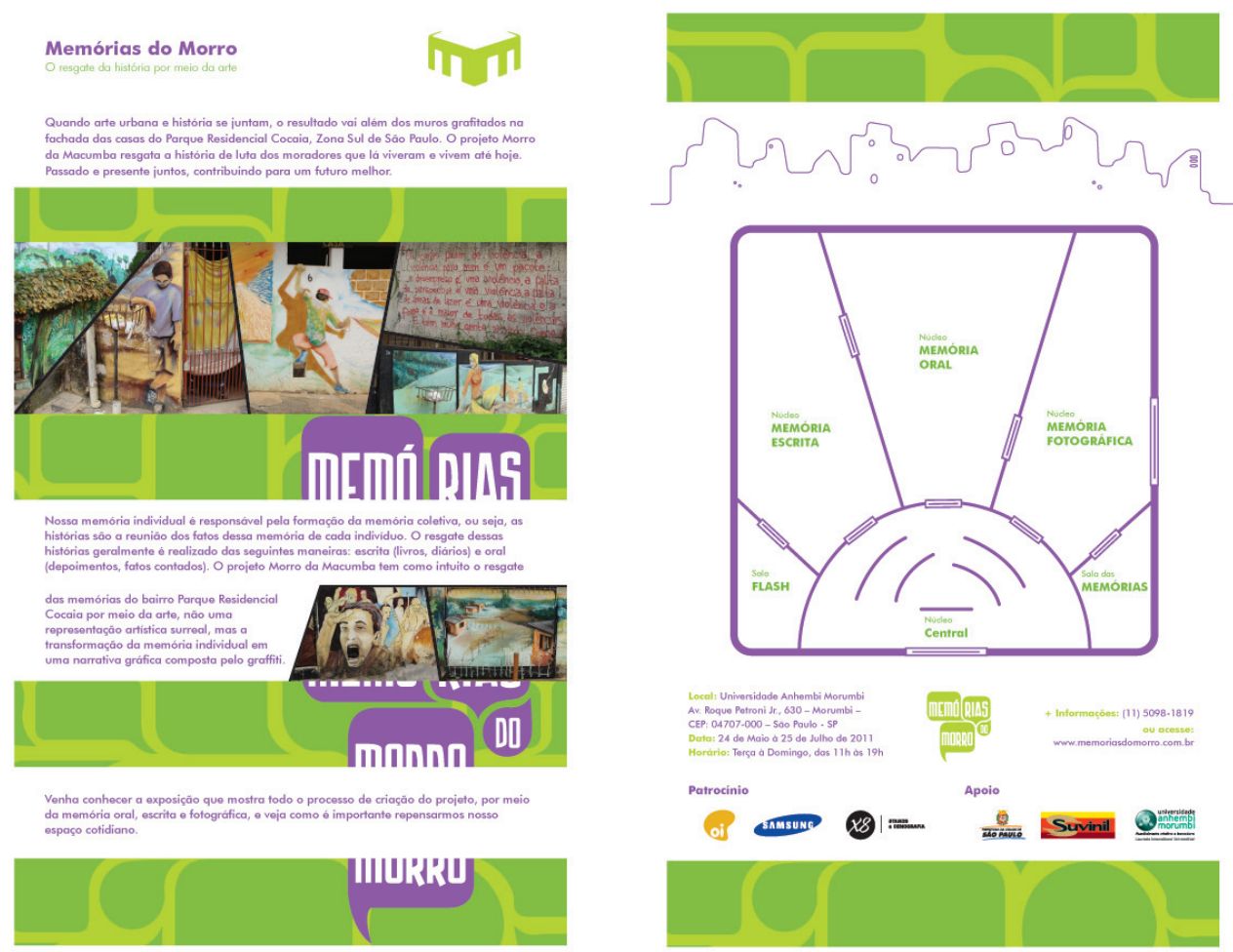

\subsubsection{Convites}

Foram elaborados dois modelos de convites, com as medidas $15 \times 10 \mathrm{~cm}$, para comunicar sobre a vernissage da exposição, que ocorrerá um dia antes da abertura para o público e contará com um coquetel e a presença dos idealizadores do projeto, que apresentarão o processo de criação do projeto original e os criadores da exposição, explicando como funciona cada uma das instalações. Esse convite será direcionado para o pessoal de outros coletivos de artistas que participem de projetos sociais; curadores, historiadores e museólogos e artistas plásticos.

O outro convite contém as principais informações para convidar as pessoas para participarem do fórum de discussão sobre a Relação da Arte, História, Cultura e Design com o espaço onde vivemos. Será enviado para todos que tiverem interesse e fizerem a inscrição pelo site.

Todos os convites terão uma versão online, estilo de E-MKT, que funcionará como um lembrete dos eventos ao qual foram convidados. 
/São coisas que a gente lembra e que guardo como

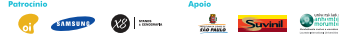
boas recordações, e outras a gente esquece///

Dalila Angioleto

Universidade Anhembi Morumbi

tem o prazer de convidar para

vernissage da exposição para a

do Morro: a transformaçáo por

meio da arte. Haverá uma palestra

bate-papo sobre o tema Design Social

na relaçáo do objeto, indivíduo e

espaço, com a participação dos criadores

do projeto Morro da Macumba e os

designers responsáveis pela exposiçẫo.
Local: Universidade Anhembi Morumbi

Av. Pogue Petroni Jr. 630 - Morumbi -

CEP: 04707-000 - São Paulo - SP

Data: 23 de Maio de 201

Horário: a partir das $19 \mathrm{~h} 30$

+ Informaçōes: (11) 5098-1819

ou acesse:

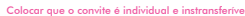

O projeto

Morro da Macumba faz

resgate da história do bairro Parque

Residencial Cocaia através das suas

Venhoras individuais e colefivas.

apresenta o processo desse projeto

por meio da memória oral, escrita e

fołográfica e veja a importância de se

repensar o espaco onde vivemos.
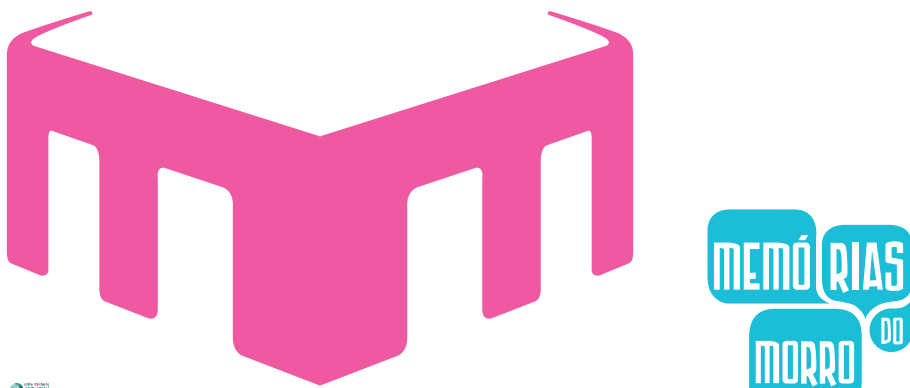

aid $1=0$

\subsubsection{Hotsite}

O hotsite é de fundamental importância para a divulgação da exposição e também funciona como uma extensão da mesma. Será um espaço online onde as pessoas poderão ter acesso as principais informações da exposição, conhecer um pouco mais sobre o projeto Morro da Macumba, além de enquetes, vídeos, fotos da exposição e do projeto, contatos, mapa de localização da exposição. Contará também com um espaço onde as pessoas poderão se inscrever para o fórum e workshops que acontecerão durante a exposição. Uma área da exposição, a sala das memórias, será representada no site também, possibilitando ao visitante a oportunidade de montar o espaço virtual com suas memórias. 


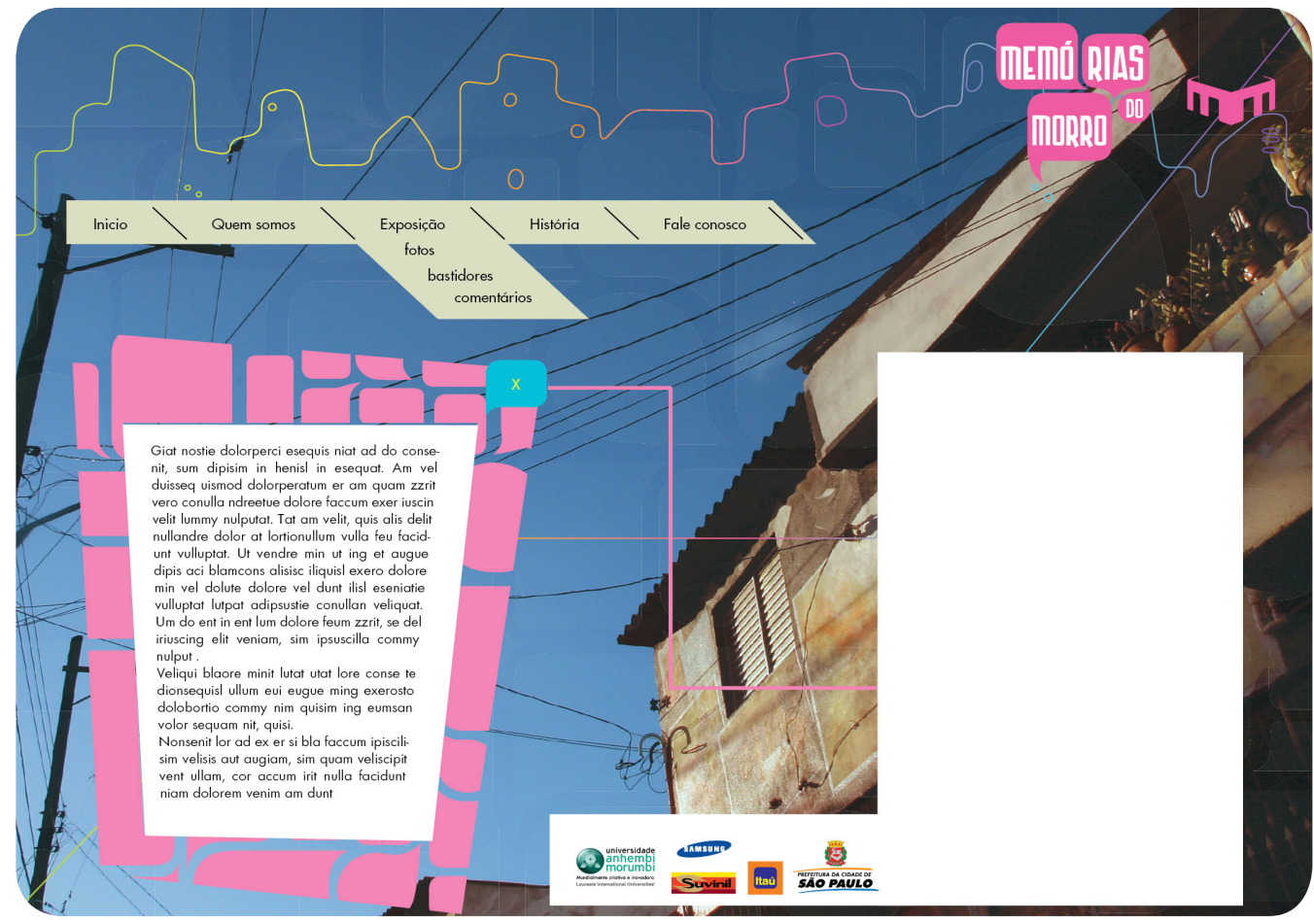

\subsection{Projeto expográfico}

Após toda a pesquisa de campo e levantamento de informações para a temática do trabalho, montamos o projeto expográfico. Este terá como temática curatorial o projeto Morro da Macumba apresentado através da memória individual e coletiva.

A estrutura da exposição é composta por quatro núcleos: central, escrito, oral e fotográfico. Esse planejamento da exposição tem como objetivo a interatividade entre público e instalações, criando assim um ciclo de troca de experiências e vivências, onde o visitante é peça importante para a composição do espaço da exposição.

\subsubsection{Planta}

A planta da exposição inicialmente foi elaborada com as divisões principais dos núcleos, onde estarão a entrada e saída, as passagens entre os núcleos. A partir desse primeiro esboço, foi possível elaborar a visão de quais materiais serão usados para compor esse espaço. 


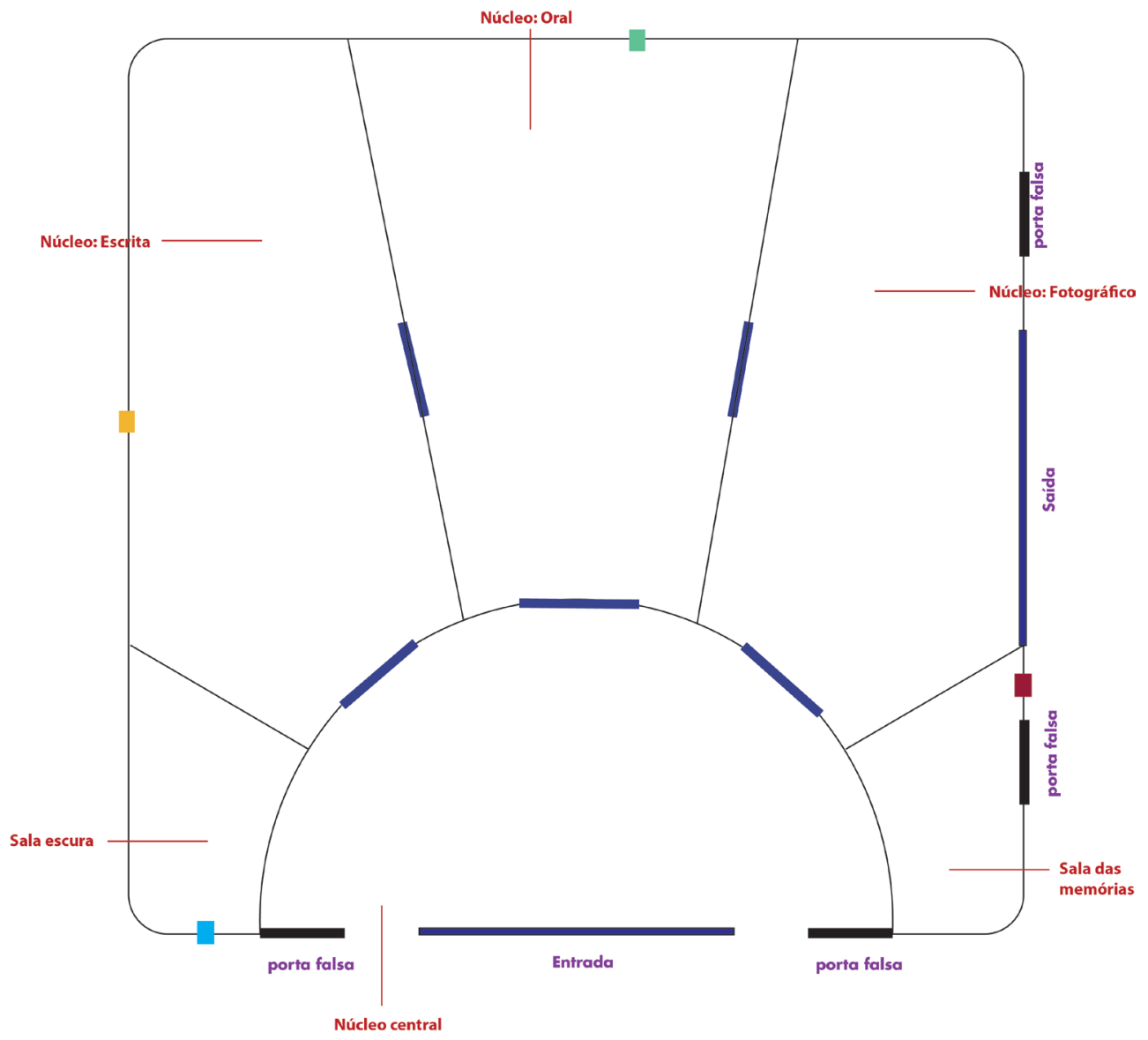

\footnotetext{
Elementos a serem construídos

Portas

Portas falsas

Nomenclatura das salas e núcleos

Parede - frente

Parede - fundo

Parede - saída

Parede - lateral
}

A estrutura base da exposição tem como objetivo a formação do elemento gráfico " $M$ ", desenvolvido para aplicação nos materiais gráficos e que representa a inicial de memórias, morro e macumba. 


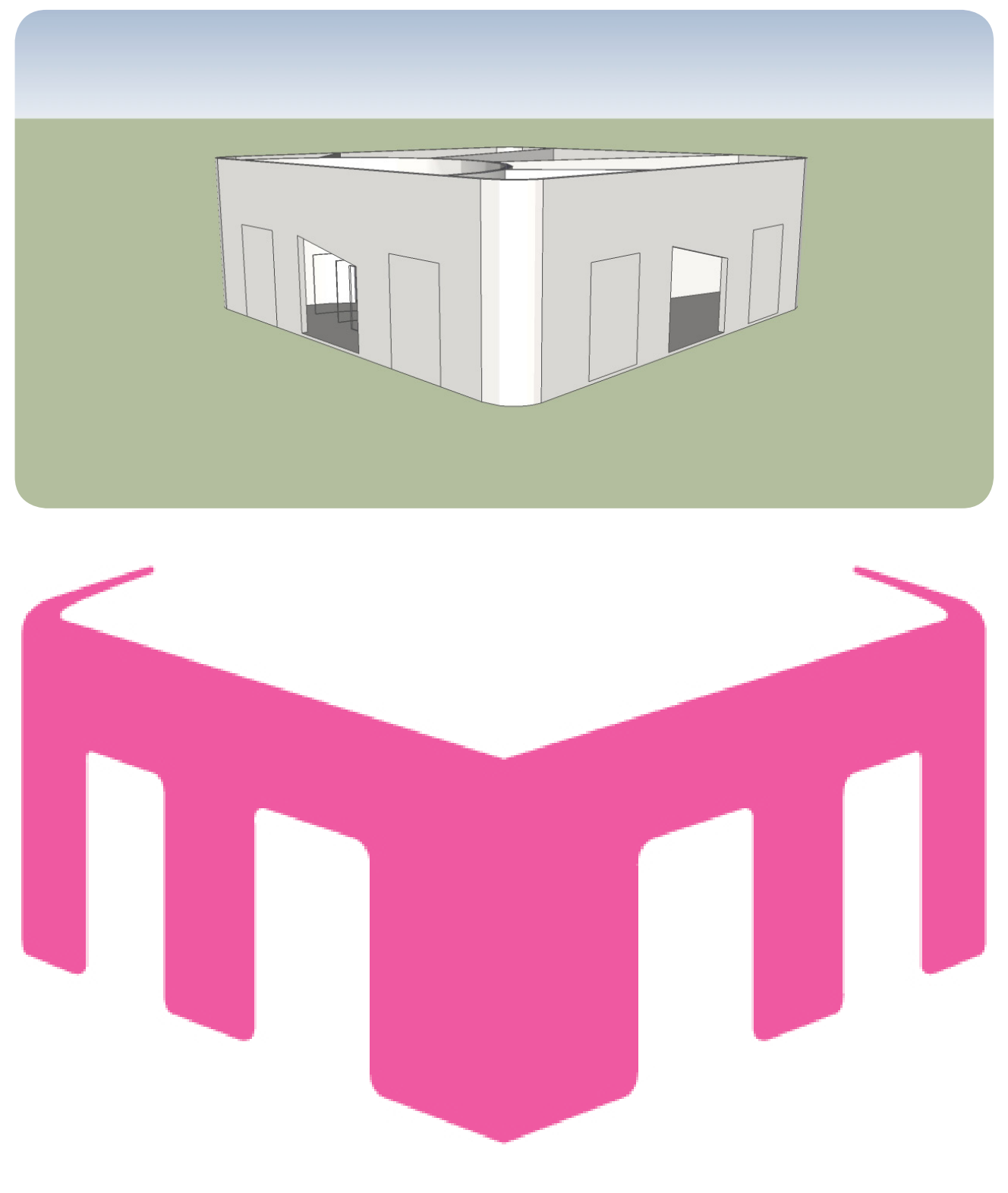

A parte externa da exposição será composta por diversos balões de fala, de diversos tamanhos, na cor branca e contorno de linha em preto.
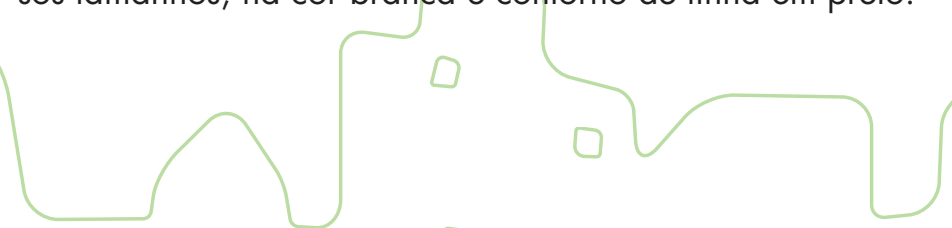
$15 \mathrm{~cm}$

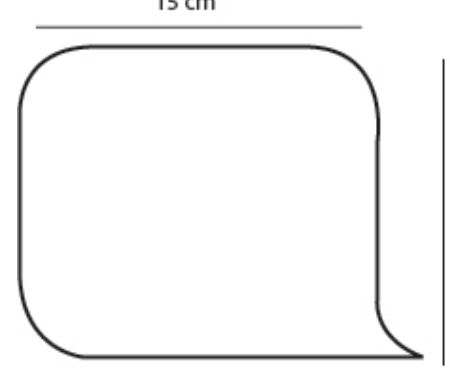

$11 \mathrm{~cm}$

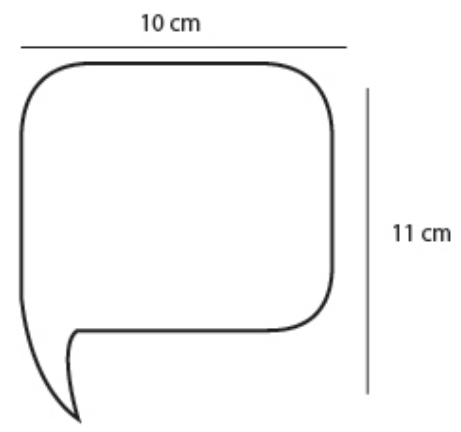

$12 \mathrm{~cm}$
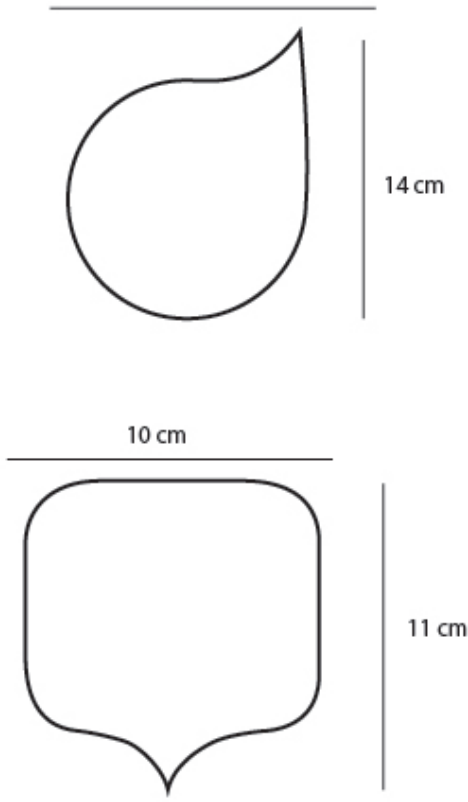

Serão colados no estilo de lambes, formando uma parede no estilo de tijolinhos. A proposta apresentada nessa parte é a de que o visitante faz parte da construção da exposição com suas vivências, curiosidades, conhecimentos e memórias. Assim, ao sair da exposição, os educadores estarão com canetas esferográficas de diversas cores e os visitantes são convidados a escreverem alguma memória ou opinião sobre a exposição, em poucas palavras, nos balões, e dessa forma, também tornando-os coautores da exposição.

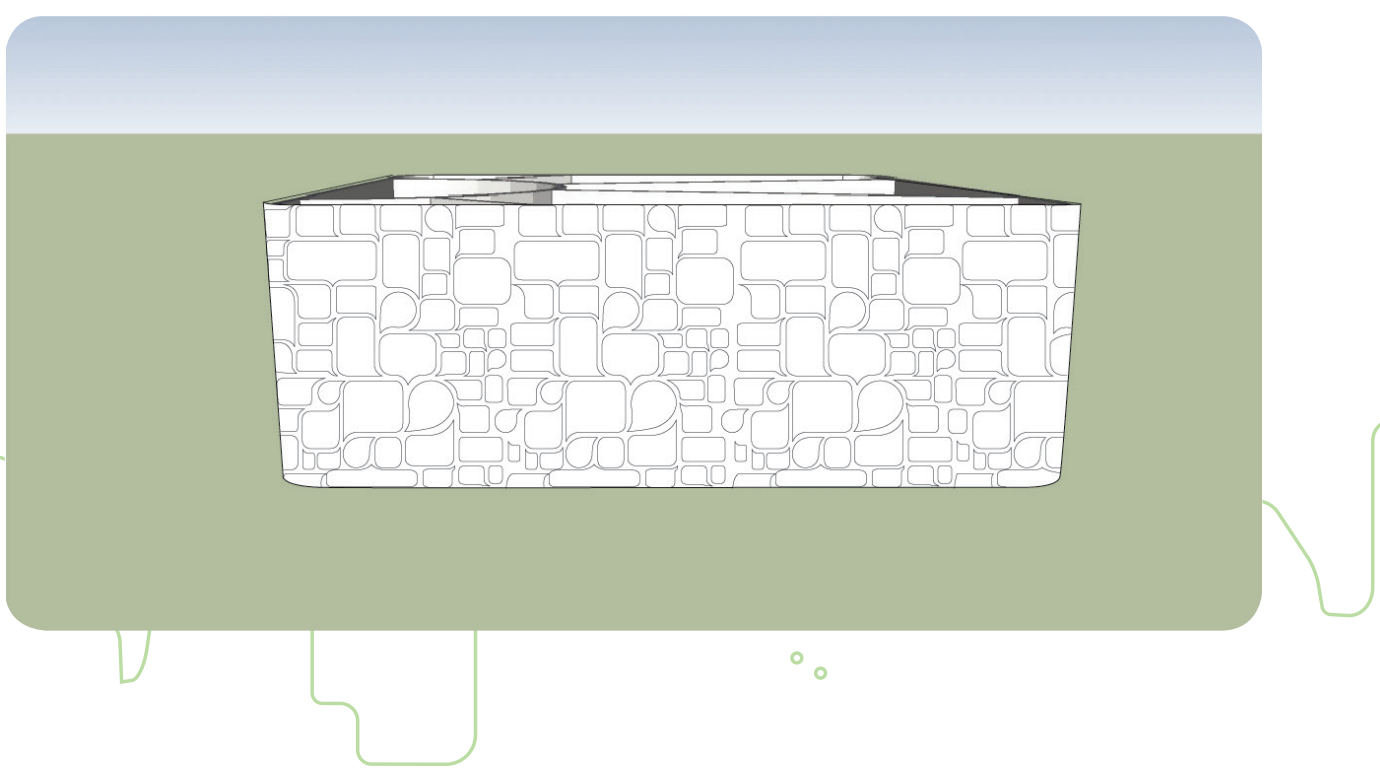


Na parte superior da entrada será aplicado um adesivo com o elemento gráfico da linha de casas do Morro com o logotipo em laranja. Essa parte não terá balões de fala. As portas falsas estarão em preto e com o adesivo dos balões em cinza.

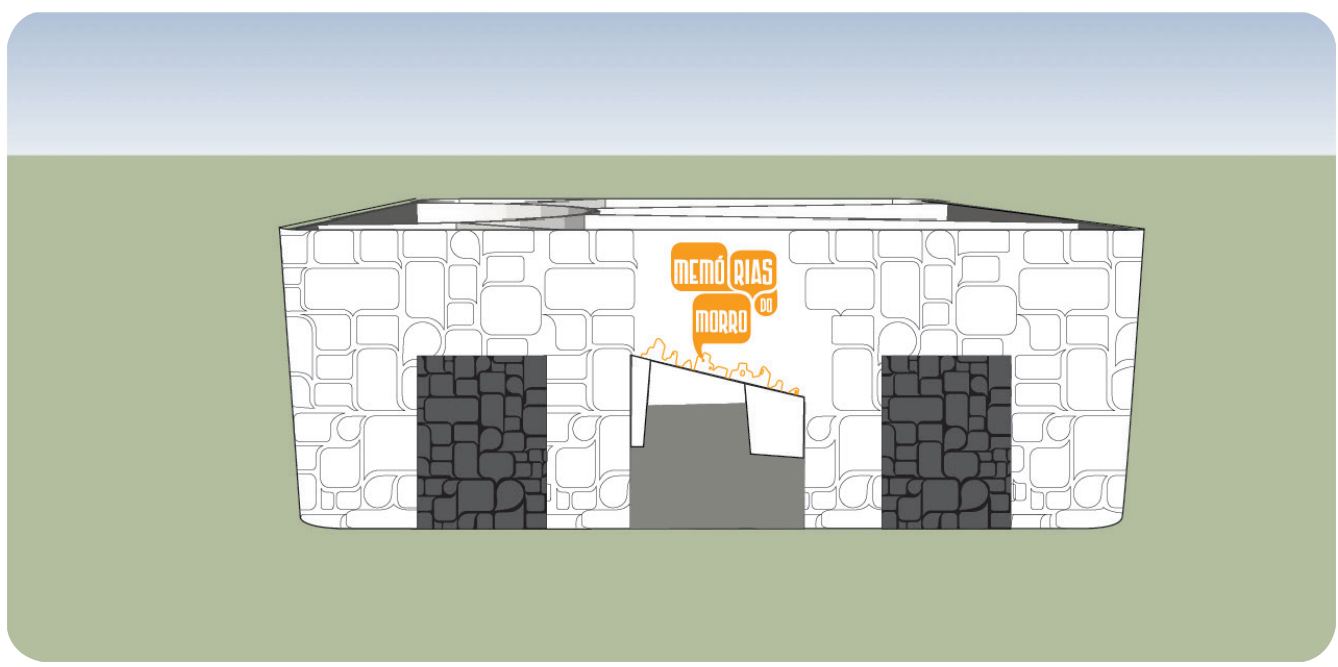

Os núcleos escrito, oral e fotográfico serão divididos por painéis de acrílico adesivados com balões transparentes para que, apesar da divisão dos núcleos, os visitantes possam observar a exposição como um todo.

\subsubsection{Núcleo central}

Ao adentrar a exposição, o visitante passará pelo núcleo central, que é o responsável por apresentar o processo do projeto Morro da Macumba por meio de uma narrativa gráfica. $O$ primeiro painel contará com uma apresentação do projeto por meio de um personagem do Morro, o graffiteiro, aquele que com suas cores, criatividade e dever social resgatou a história no qual resultou o projeto Morro da Macumba e essa exposição. Foi uma vontade dele, um sentimento de "obrigação" em fazer algo pelo lugar onde vive. 

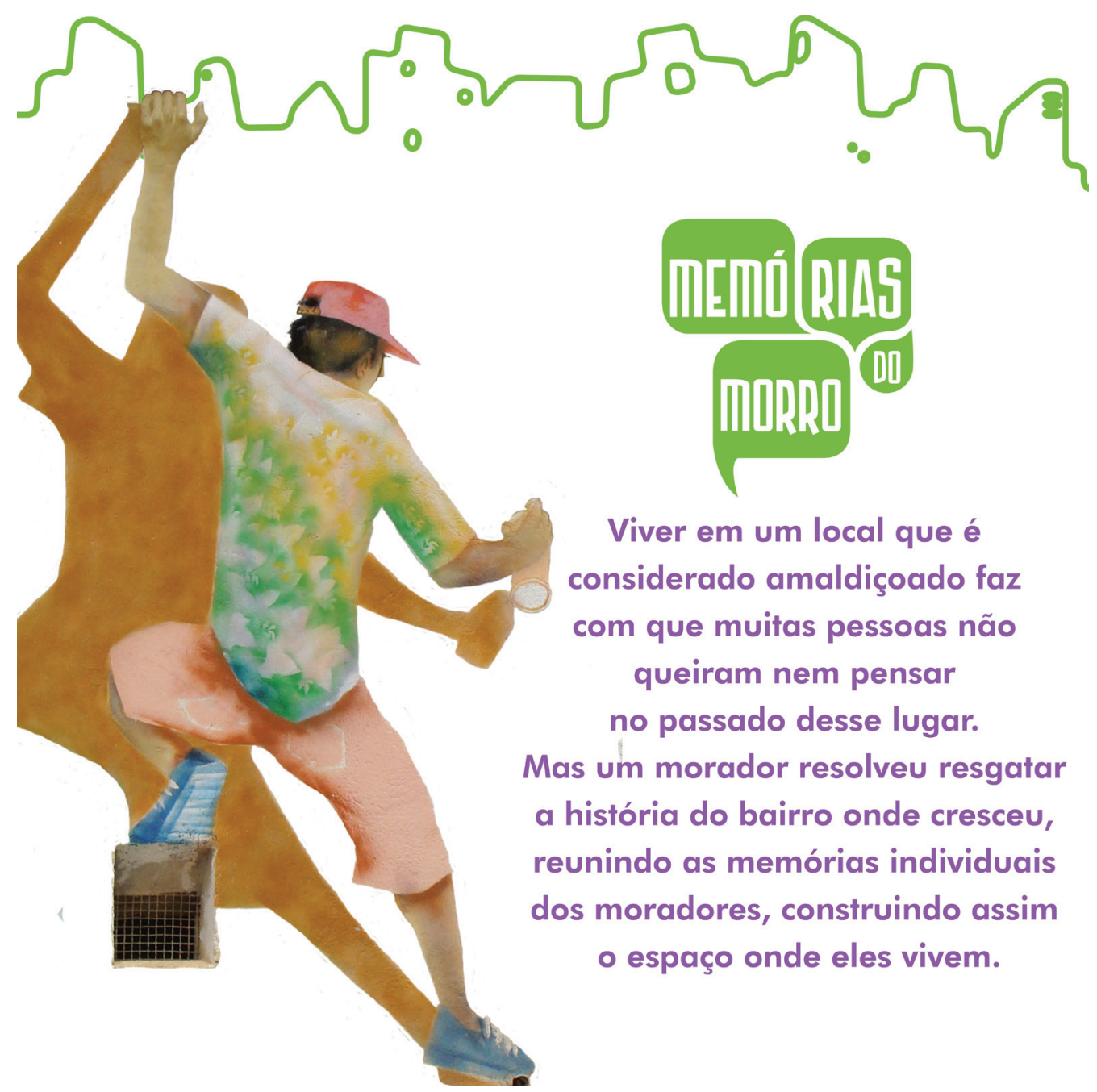

Viver em um local que é considerado amaldiçoado faz com que muitas pessoas não queiram nem pensar no passado desse lugar. Mas um morador resolveu resgatar a história do bairro onde cresceu, reunindo as memórias individuais dos moradores, construindo assim o espaço onde eles vivem.

Ao lado, estará uma banca de infomações e para retirada de alguns materiais:

- Catálogo - geralmente, os catálogos das exposições são distribuídos na pósexposição e para alguns selecionados. Pretendemos colocar o catálogo à disposição do público desde o início da exposição. Ele contará com a história do projeto Morro da Macumba e do bairro Parque Residencial Cocaia, além de um diferencial: como toda a exposição foi elaborada e pensada. Dessa meneira, destacar a importância que se pensar o espaço tem para o resultado final. Cada detalhe de como tudo foi pensado são as nossas memórias individuais para a formação de uma memória coletiva, que se realiza na exposição final. 

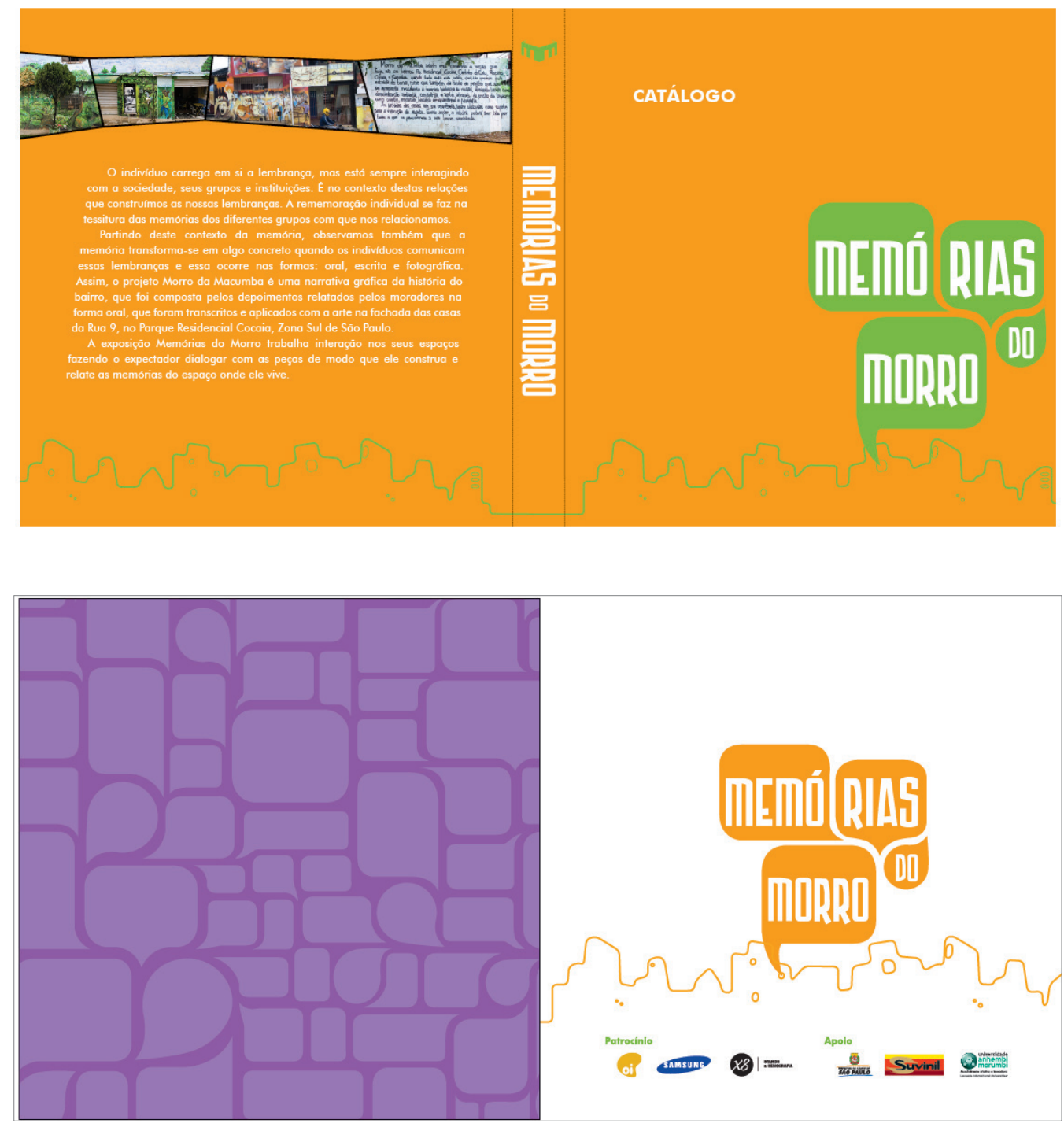


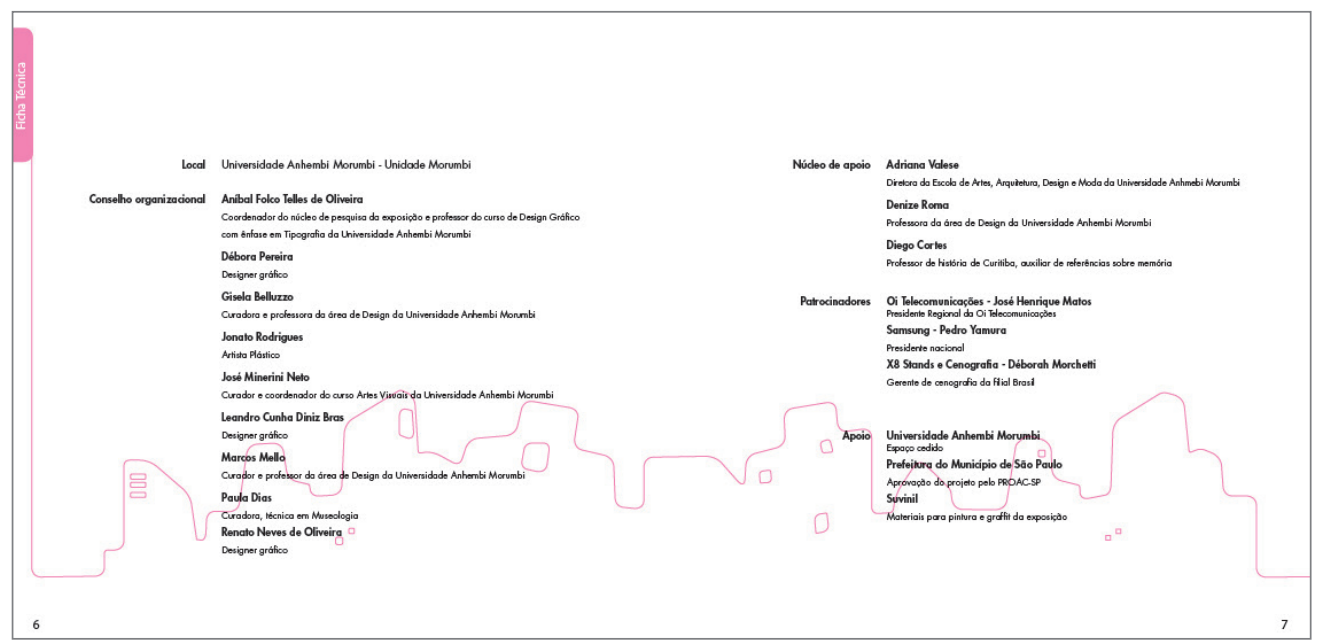

- Óculos - serão utilizados para uma parte específica da exposição. Como é uma exposição interativa, os depoimentos estarão escritos em alguma parte da instalação e somente será possível sua leitura com os óculos especiais. Um jogo de palavras estará nas legendas, palavras embaralhadas num primeiro momento e com as cores verde, amarelo e vermelho. Ao colocar os óculos, o visitante enxergará somente as letras em verde, o restante será "apagado" pelo acetato vermelho.

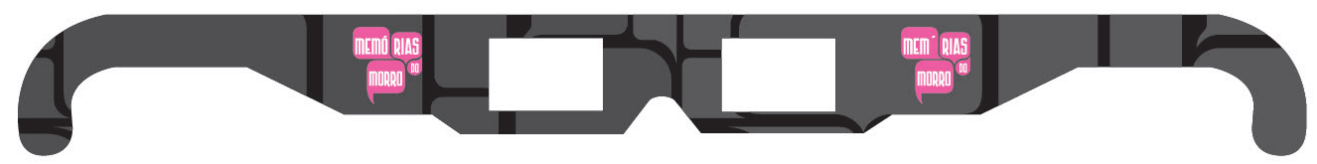

- Brindes - Para reforçar a imagem da exposição, um adesivo com o logotipo será confeccionado e entregue a cada espectador que visitar a exposição. Além disso, serão entregues marcadores de livros de imãs.
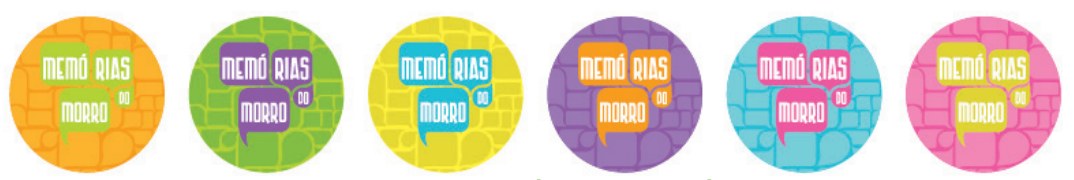

mEறÍ் RIAS
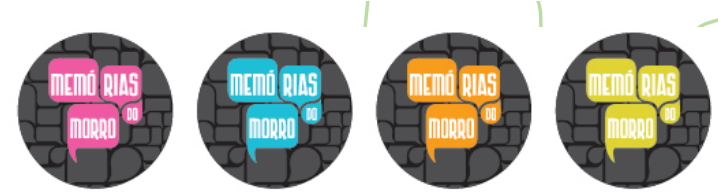

memí puas

manRo

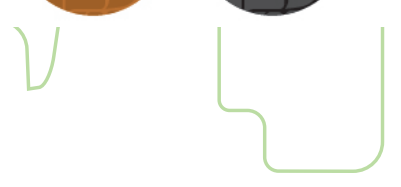



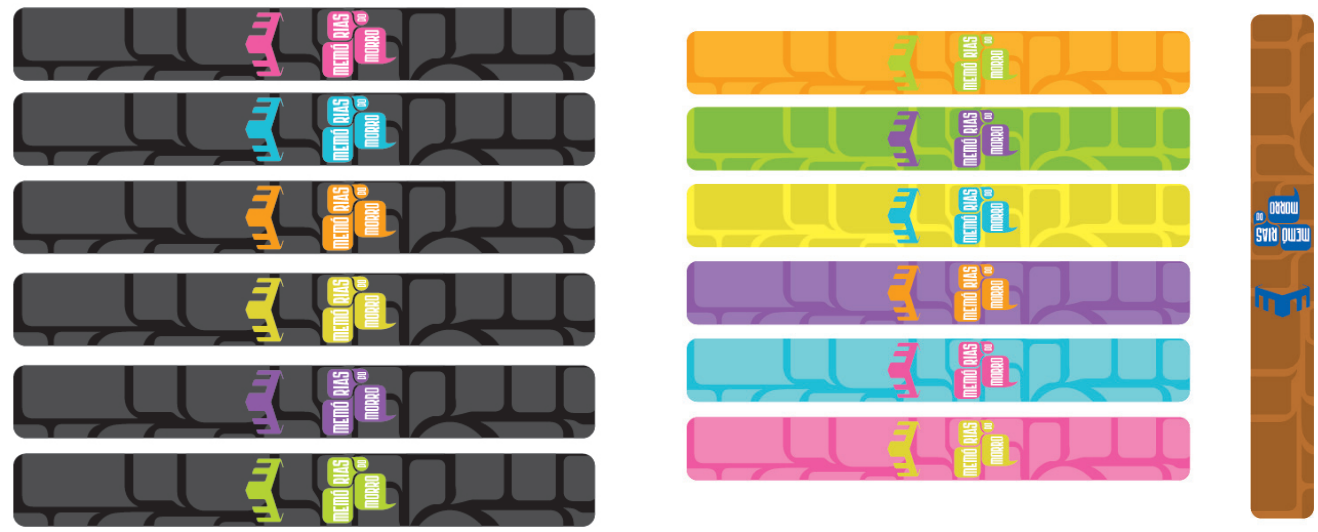

Os demais painéis apresentam, por meio de relatos da história do projeto, os caminhos percorridos para alcançarem a transformação visual do espaço onde eles vivem.
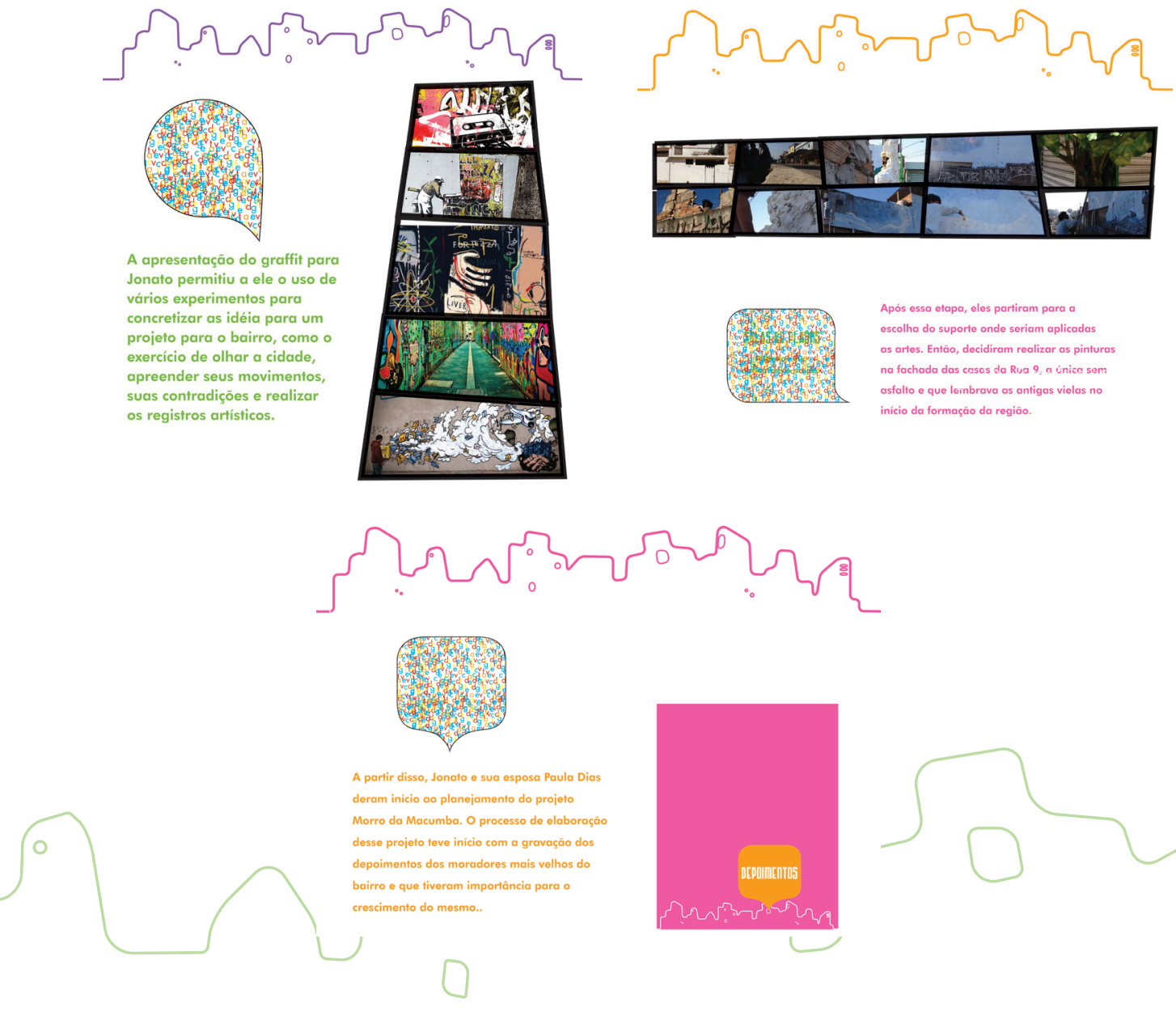

Após essa otapa, eles partiram para a escolha do suporte onde seriam aplicadas as artes. Então, decidiram realizar as pinturas na fachada das casas sla Rua 9, a unize sum asfalto e que leinbrava as antigas vielas no inicio da formaçāo da regiáo.

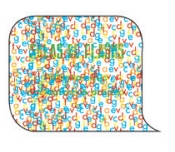


Esses painéis contaram com legendas de identificação das fases ao qual representam. Essas legendas, terão o formato dos balões e para ler seu conteúdo, serão utilizados os óculos distribuídos na entrada.
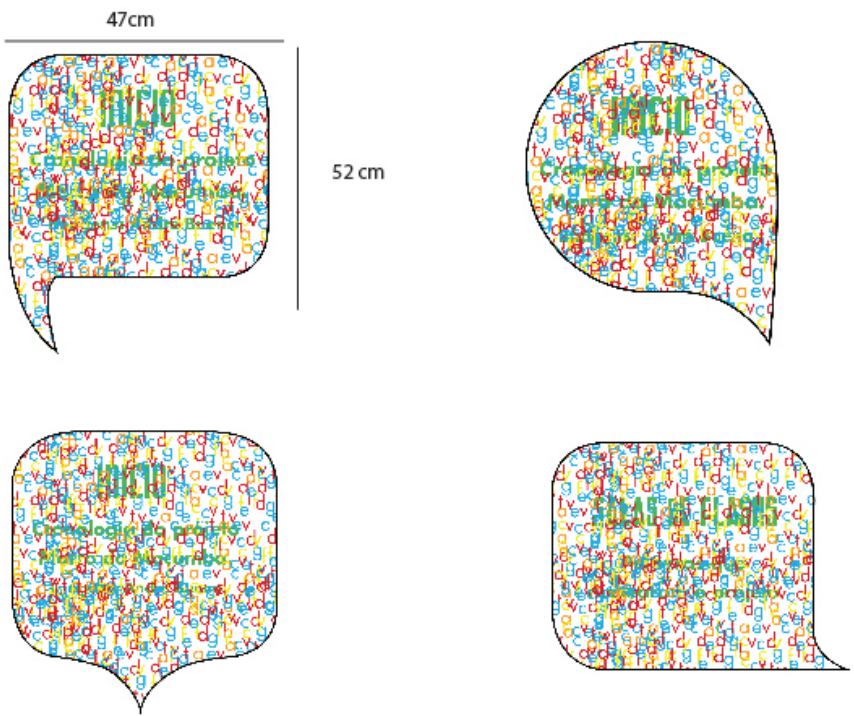

Essses painéis contarão com metiês em preto, onde serão coladas com adesivo as imagens. Esses quadros serão presos por um gancho que os deixarão saltados da parede, para não ficar algo simples e sem interação.

Nas paredes no entorno desse núcleo, será possível notar as histórias em quadrinhos do processo para elaboração do projeto no bairro Parque Residencial Cocaia.
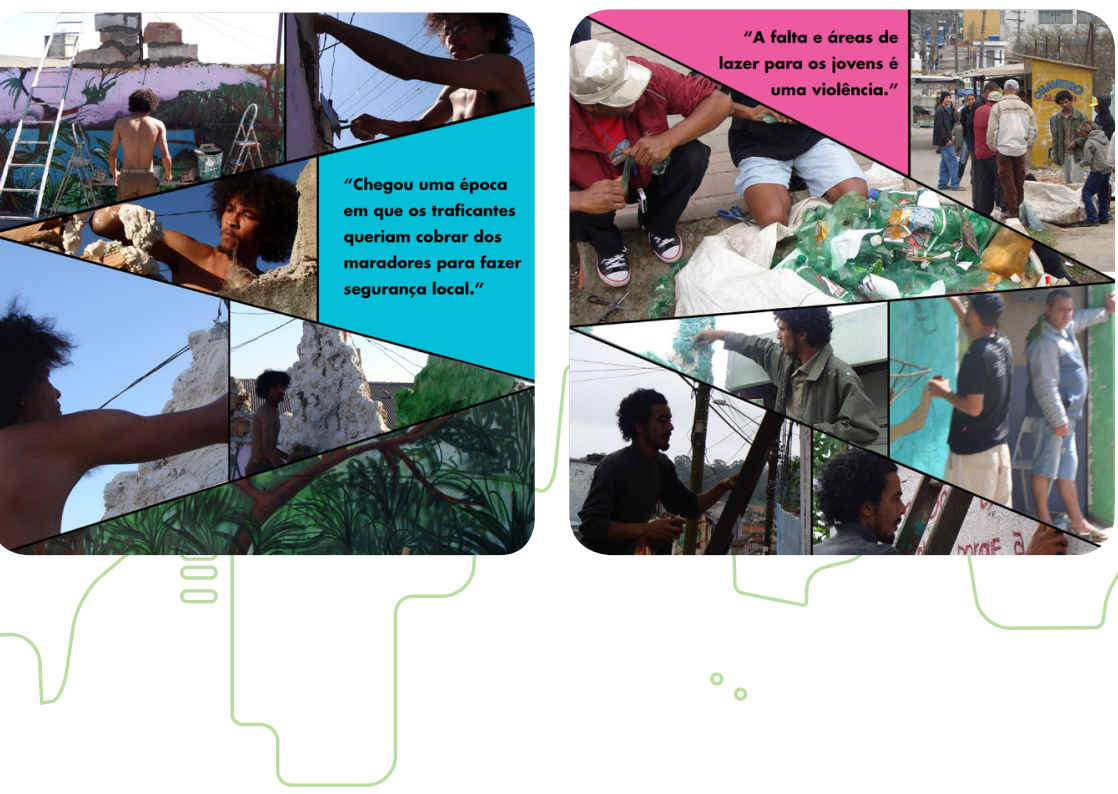


\subsubsection{Núcleo escrito}

O núcleo das memórias escritas representa todos os depoimentos que foram utilizados durante o projeto Morro da Macumba em sua foram escrita. Nessa área serão montadas instalações que apresentam a importância da memória escrita para a busca de identidade de cada indivíduo.
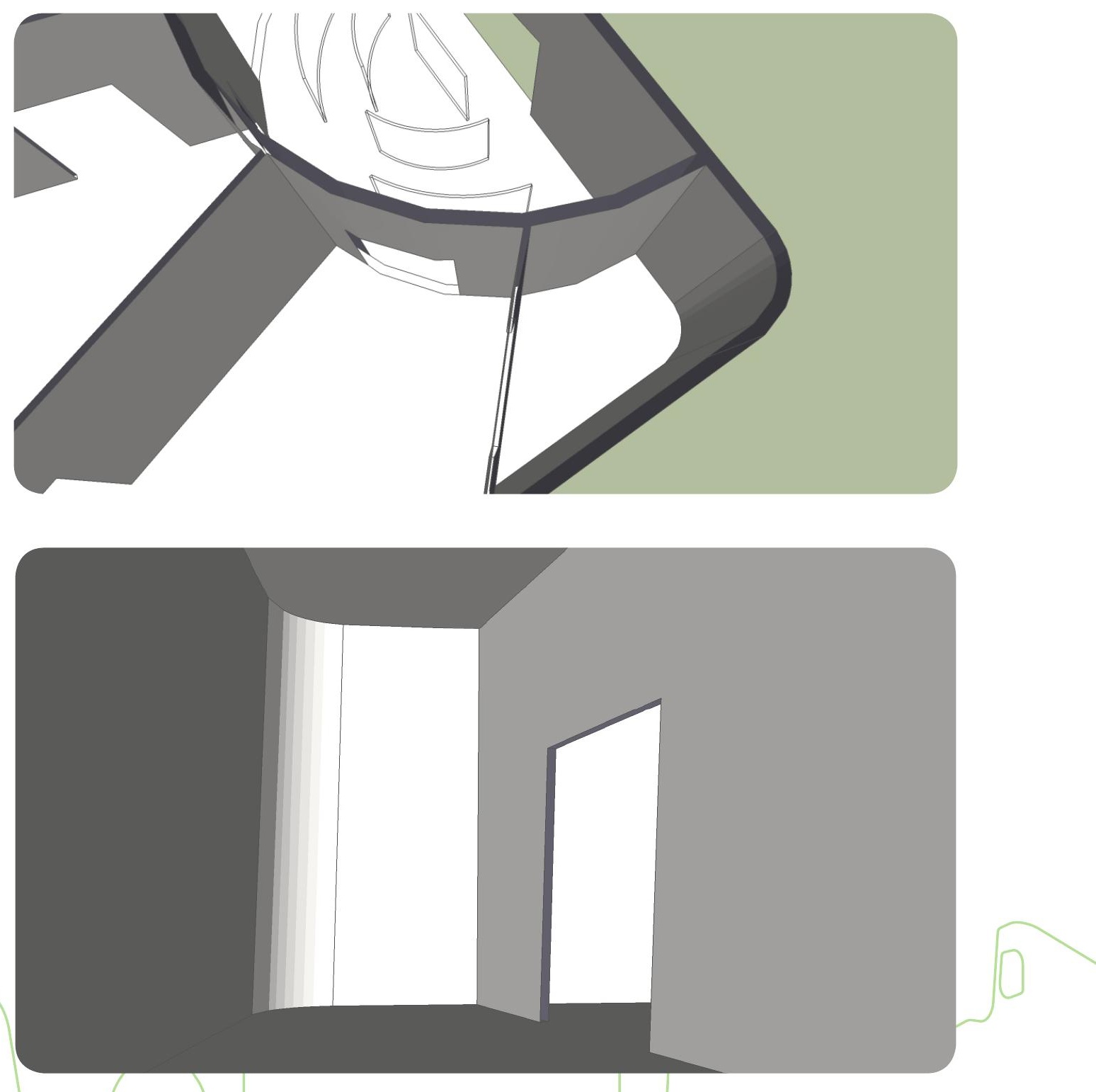

Teremos porta-folders espalhados onde o visitante poderá retirar um dos cartazes da exposição para levar para casa como recordação. 

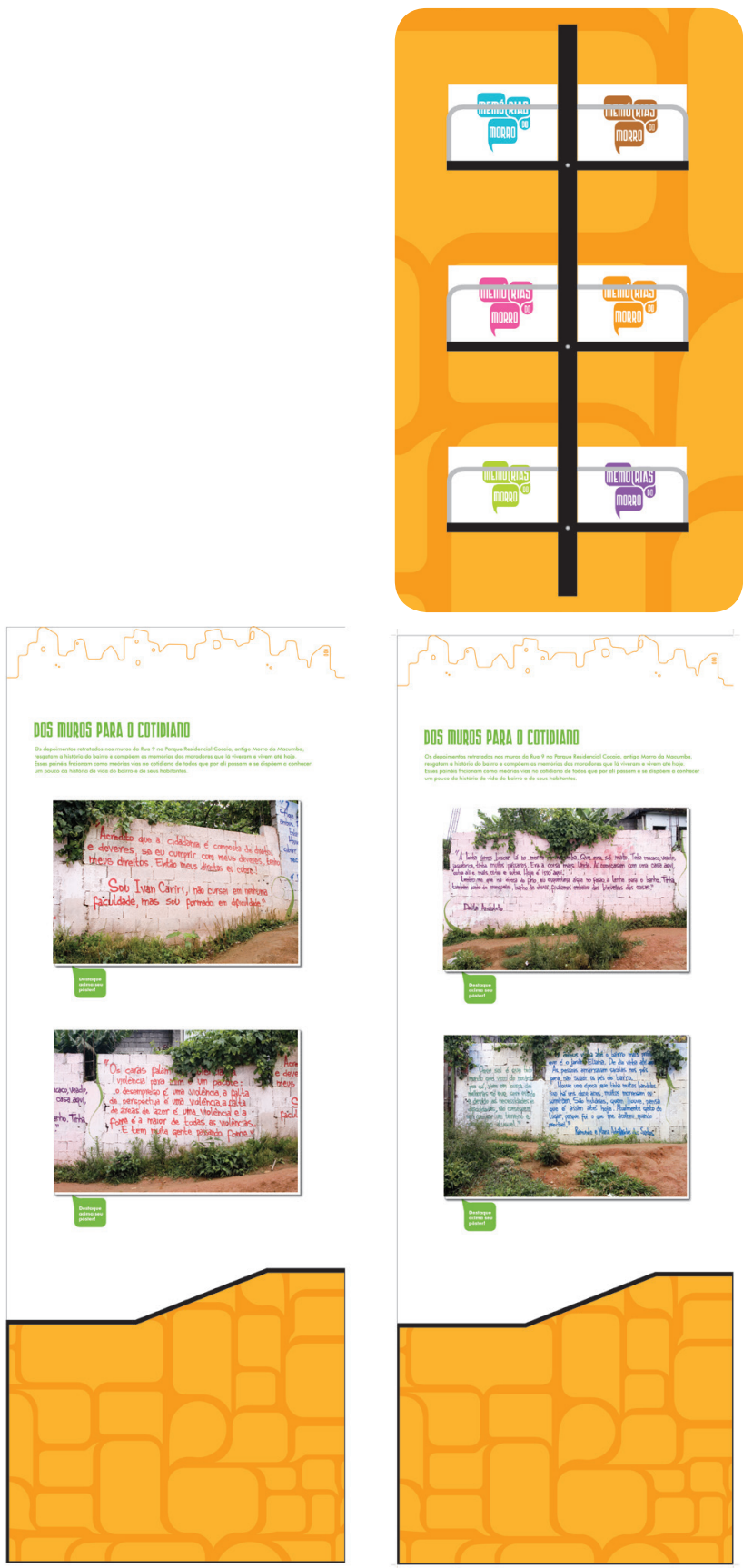

Atrás desses porta-folders, ficarão os porta-postais que o visitante também poderá retirar como recordação dessa exposição. Esses postais conterão as palavras que nortearam esse projeto.

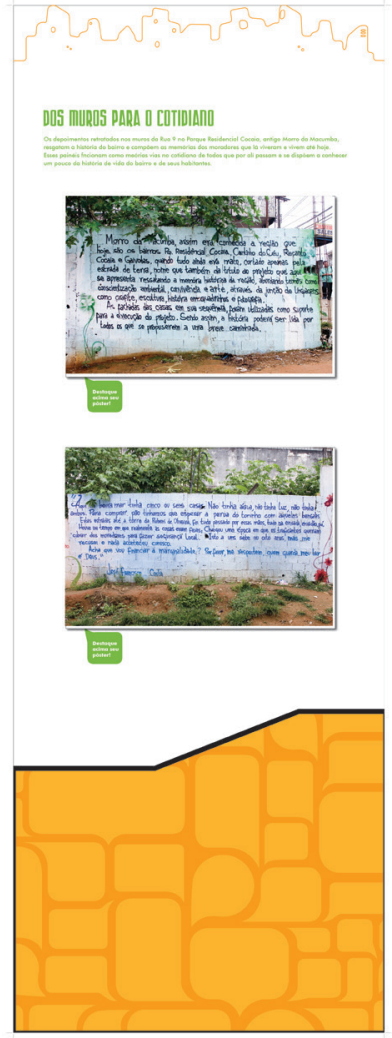

DAS MURDS PARA o COTIDIATO
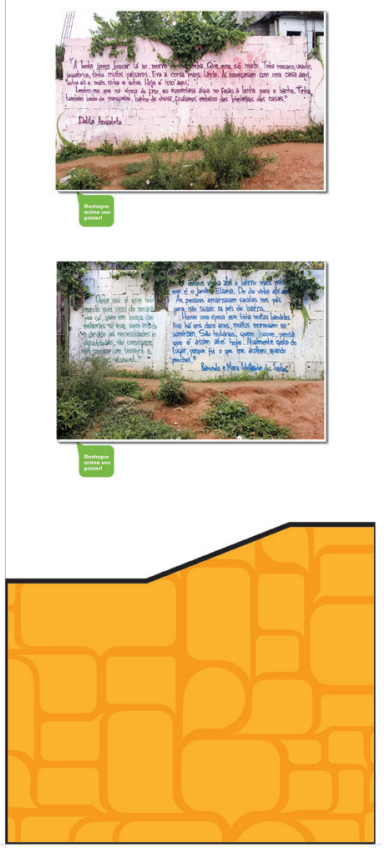

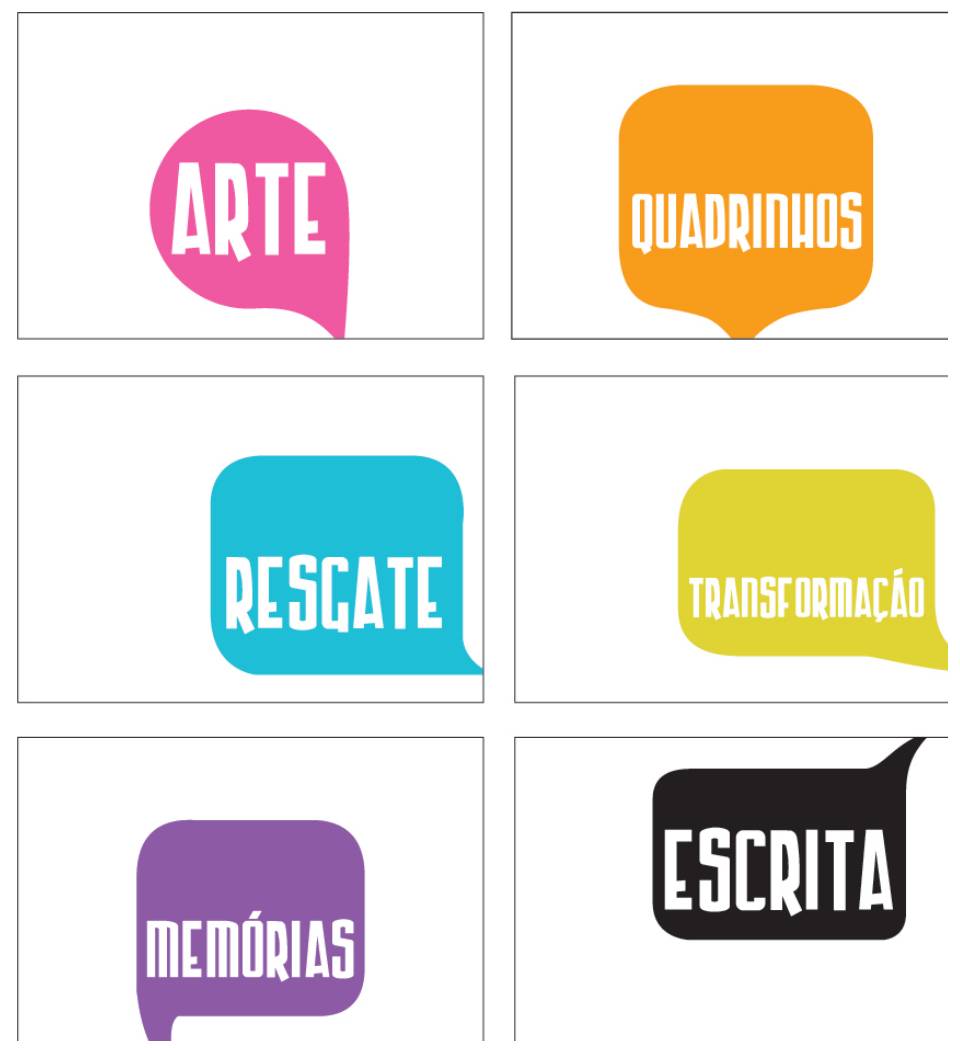

- Nesse núcleo também teremos uma sala escura de flashes de depoimentos de Ivan Cariri, um dos principais moradores do bairro Parque Residencial Cocaia.

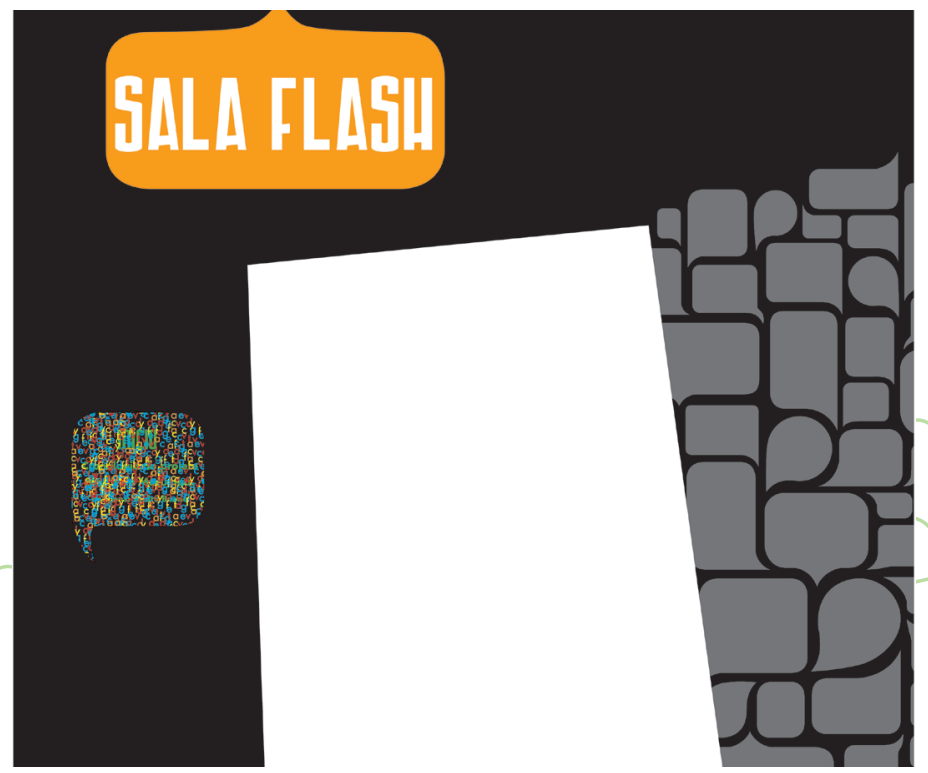



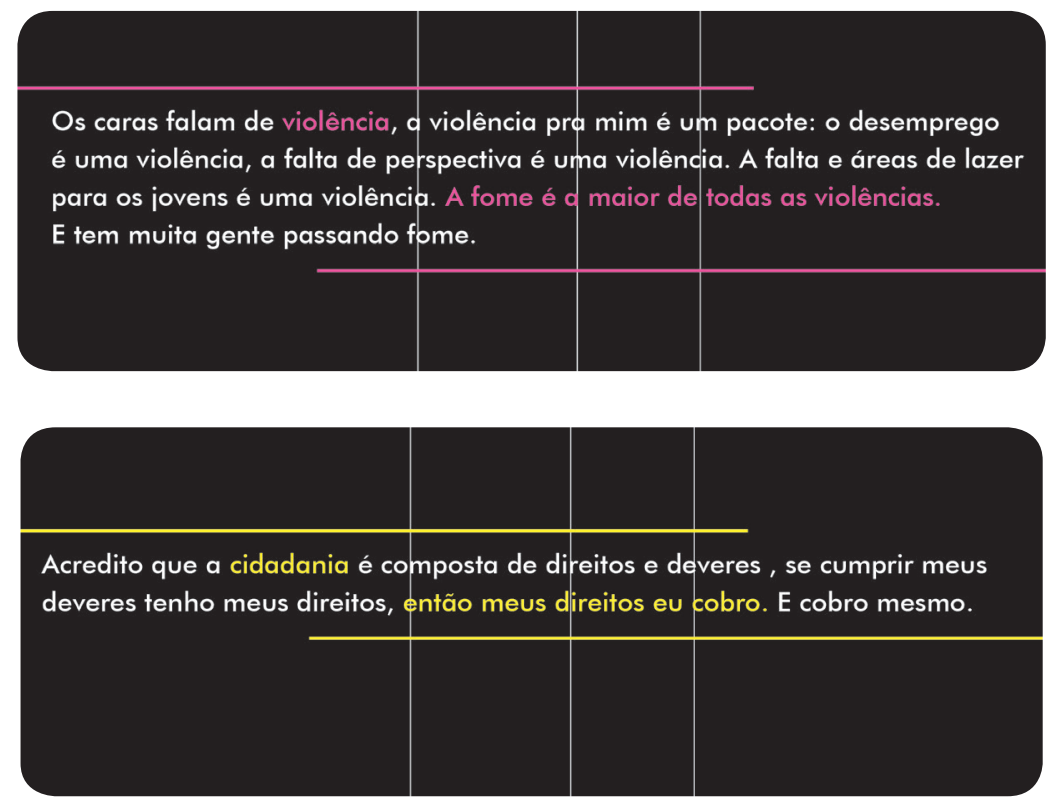

- Varal das memórias - será colocado um varal onde serão pendurados folhas em branco. Serão projetadas nessas folhas diversas palavras que compõe o projeto.

- Porta dos depoimentos - na parede principal desse núcleo, serão colocadas três portas, em formato de madeira, grade e ferro. Ao abrir as portas, os visitantes se depararão com os depoimentos que foram graffitados nos muros da rua 9, no bairro Parque Residencial Cocaia.

\subsubsection{Núcleo oral}

O núcleo das memórias orais será responsável por apresentar o projeto Morro da Macumba por meio dos mais diferentes tipos de áudios.

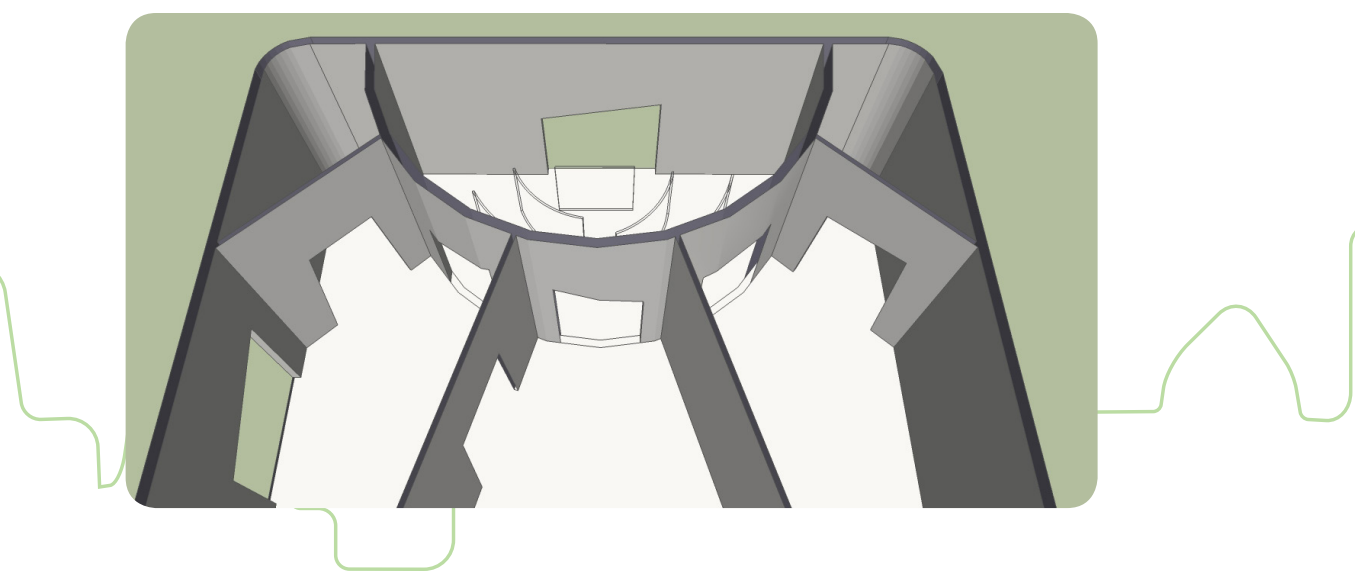


As sensações causadas pelos diversos sons presentes no bairro e quais lembranças isso provoca no visitante.

- Caixas de recordação - serão espalhadas quatro caixas no espaço desse núcleo. Ao abrir as caixas, os visitantes ouvirão alguns depoimentos dos moradores do bairro Parque Residencial Cocaia.

- Audiovisual - estarão espalhadas nas paredes, placas de protesto com telas apresentando os vídeos gravados sobre o projeto. Esses vídeos serão a representação visual das principais caraceterísticas presentes no processo do projeto.

- Bluetooth - serão disponibilizados depoimentos do projeto Morro da Macumba via bluetooth para os visitantes que estiverem com os celulares habilitados.

\subsubsection{Núcleo fotográfico}

O núcleo das memórias fotográficas apresenta as memórias do projeto por meio de fotografias e de interação. $\bigcirc$ visitante é convidado a participar da montagem das memórias por meio de instalações:

- Jogo das memórias - nessa instalação a pessoa é convidada a participar de um jogo interativo de cartas, no estilo jogo das memórias. Essas cartas terão as imagens das fachadas das casas e noverso estarão o logo da exposição aplicado no fundo branco.

- Monta-imagens: essa instalação será composta por painéis com as imagens do projeto embaralhadas. $\bigcirc$ visitante é convidado a interagir coma instalação, montando suas peças.
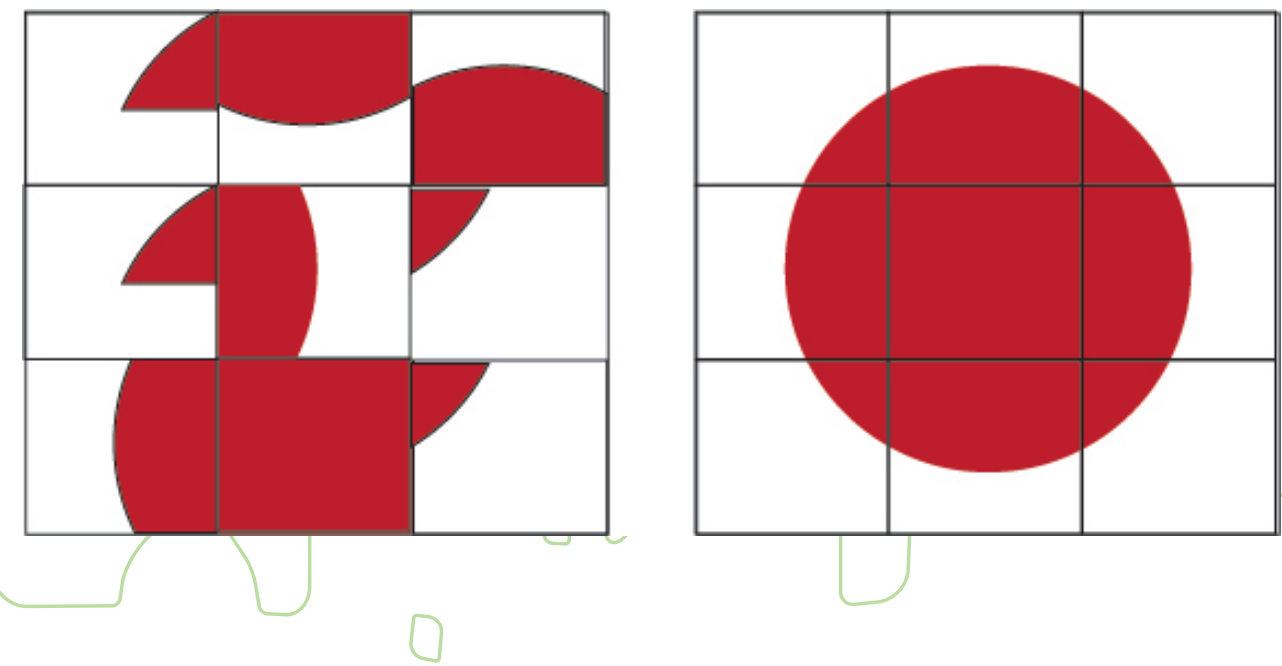
- Monóculos - essa instalação vem a ser uma recordação. Quem não se lembra dos monóculos, umas das primeiras formas de ser ver as fotos? Nesse espaço, o visitante poderá observar por monóculos de diferentes formatos algumas imagens que compõem o projeto Morro da Macumba.
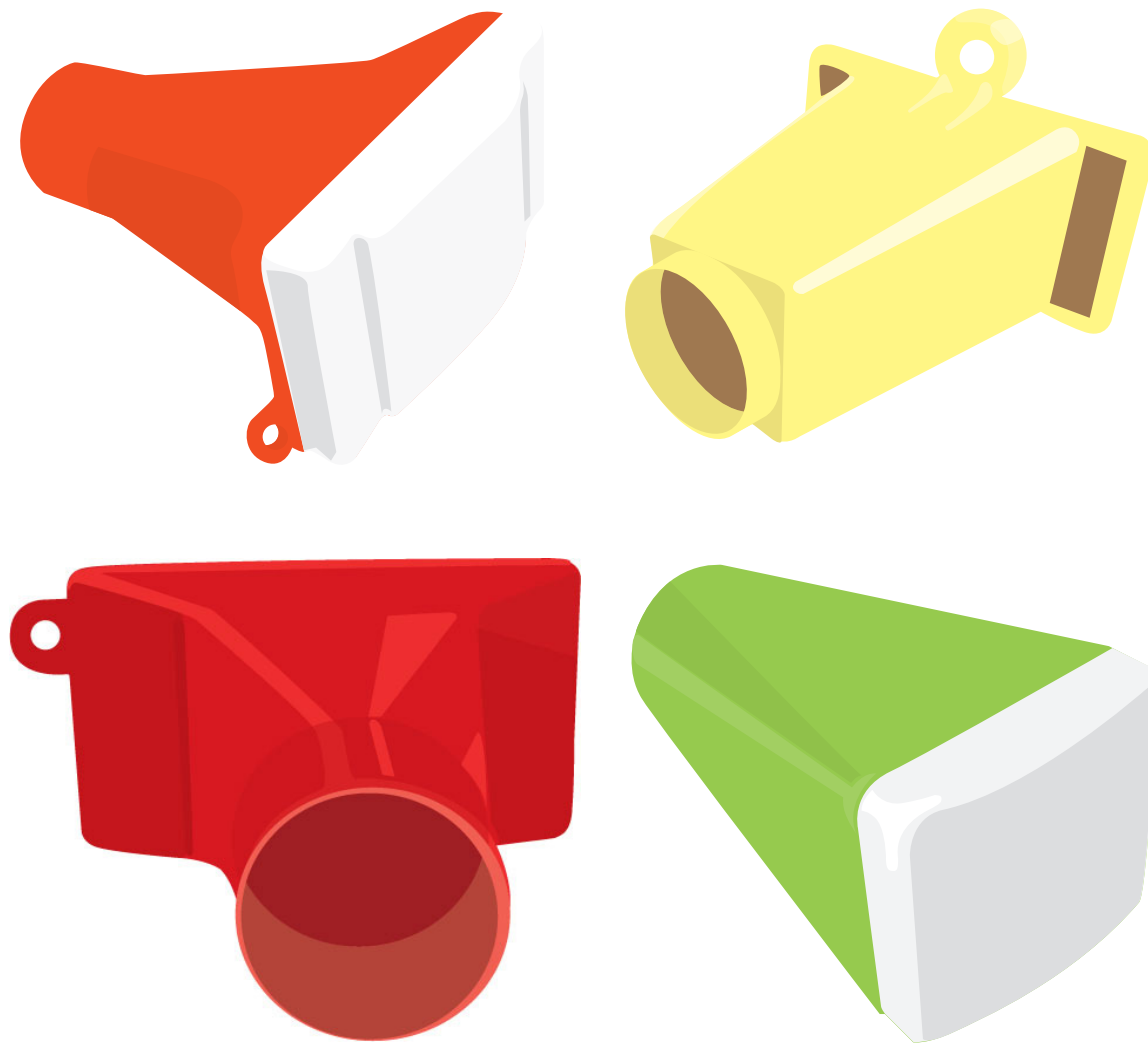

- Porta-retratos - nessa instalação, o visitante verá porta-retratos gigantes com imagens dos principais detalhes das fachadas das casas, como por exemplo, os elementos dos graffiti que interagem com os elementos presentes nas casas.

Toda a exposição será uma parceria com os criadores do projeto Morro da Macumba. Procuraremos representar nas instalações os elementos interativos que foram utilizados para a composição do projeto original, além de algumas paredes terem os graffitis resproduzidos novamente por eles. É importante destacar que essa troca de experiências na montagem transformaram a exposição em um verdadeiro convite para que os visitantes conheçam as Memórias do Morro, que formam e transformam o espaço onde eles vivem.

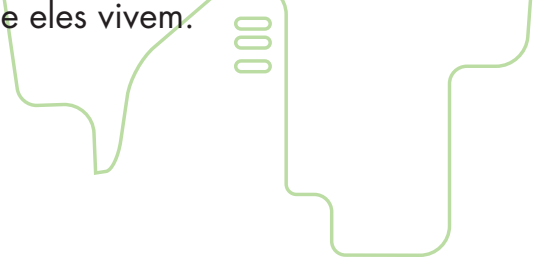

